\title{
Ground to air and back again: archaeological prospection to characterize prehispanic agricultural practices in the high-altitude Atacama (Chile)
}

\author{
César Parcero-Oubiña ${ }^{a}{ }^{*}$, Pastor Fábrega-Álvarez ${ }^{a}$, Diego Salazar $^{b}$, Andrés Troncoso ${ }^{b}$, \\ Frances hayashida $^{c}$, Mariela Pino $^{b}$, César Borie $^{d}$, Ester Echenique $^{e}$
}

${ }^{a}$ Instituto de Ciencias del Patrimonio (Incipit), Consejo Superior de Investigaciones Científicas (CSIC). Santiago de Compostela. Spain.

${ }^{\mathrm{b}}$ Facultad de Ciencias Sociales, Universidad de Chile. Santiago de Chile. Chile.

${ }^{\mathrm{c}}$ Department of Anthropology, University of New Mexico. Albuquerque, NM. USA.

${ }^{\mathrm{d}}$ Universidad Católica del Norte. Arica. Chile.

${ }^{\mathrm{e}}$ School of Anthropology, University of Arizona. Tucson, AZ. USA.

*Corresponding author: cesar.parcero-oubina @incipit.csic.es

\section{Abstract}

In this paper we present an overview of the process of mapping and field surveying of an area of ancient fields and irrigation canals around the pre-Hispanic sites of Topaín, Paniri and Turi, in the Andean highlands of northern Chile. As opposed to the usual conditions for prospection in temperate or tropical regions, where the surface visibility of archaeological features is often poor and confusing, here the extreme aridity of the landscape has permitted an extraordinary degree of both preservation and visibility of the fields, canals and other constructions. A field methodology based on a combination of an aerial approach (with relatively low-cost resources: high resolution satellite images, GIS, UAV) and field survey has allowed us not only to document the sites but to 
inject some order into a large assembly of archaeological features: to understand how the system as a whole was built, and how it evolved and changed in time, thus allowing for the proposal of a sound hypothetical sequence of the use and transformation of this area before and after the Inka period.

Keywords: Aerial archaeology; Stratified random sampling; Agrarian landscape; Late Intermediate Period; Inka Period; Northern Chile

\section{Introduction}

In an unlikely place, the high-altitude Atacama Desert of northern Chile, the driest desert in the world, farming communities built extensive canal and terrace systems during the so-called Late Intermediate Period (from ca. AD 1000) that were appropriated, modified, and expanded following conquest by the Inka Empire in ca AD 1400 (Llagostera, 1976, P. Núñez, 1991,1993, Santoro et al., 1998). The Inka conquered this region not for its agricultural potential but rather for its tremendous mineral wealth, (L. Núñez, 1999, Salazar, 2008, Salazar et al., 2013) as this was and is a major copper producing region. The Inka expanded mining installations, and built roads, way stations and administrative centers to organize and control them (Uribe et al. 2002, Aldunate et al., 2003, Castro et al., 2004, Berenguer et al., 2005, Berenguer, 2007, Salazar et al., 2013). Food was needed both to provision state personnel and laborers, but also to serve at feasts in displays of imperial hospitality that helped ensure the upward flow of tribute (Acuto 2012).

Even though several agricultural sites are known for the area (Pollard, 1971, Santoro et al., 1998, Aldunate, 1999, Le Paige, 2007), they have not been systematically studied, the main reason being the extension of these sites and their complex nature which makes recording and mapping a highly difficult and costly task (Malim, 2009). However, understanding the ecology and 
organization of water management and farming in this extreme environment, and their relationship to larger political and historical processes is fundamental to reconstructing the Late Prehistory of the Atacama. In order to address this issue, in 2010 we begun a research project in the interfluvial region between the Loa and Salado rivers, in northern Chile. How did farmers make a living? How did they organize themselves to manage water, land and crops? And what happened to farming livelihoods and landscapes when they were pulled into the Inka political economy?

Addressing those questions in this particular environment poses a series of opportunities and challenges, due especially to the excellent preservation of the archaeological features and the vast amount of evidence available on the ground. This encouraged us to develop a multiscale approach, based on a combination of different field and aerial methods. This paper presents some of the results of these efforts, developed by a team composed of Chilean, Spanish and North American archaeologists, botanists, geoarchaeologists and anthropologists. In particular, we focus on our study of the construction, use and transformation of the cultivation areas using a combination of mapping, stratigraphic analysis and field survey.

\section{Regional setting}

The study area is located in northern Chile, close to the Bolivian border (Figure 1). Geographically, the area is known as the Alto Salado and belongs to the upper basin of the Loa River, the longest in Chile. This is an environmentally extreme area, $80 \mathrm{~km}$ north of San Pedro de Atacama. Among the geographical characteristics of the area, the extreme dryness is perhaps the most remarkable: this is considered as the driest place on earth. The landscape is typically a desert: most of the land consists of either desert terrain or sparse scrubland, although in some 
specific places the availability of water from rivers (Loa, Salado) or springs (Turi, Paniri, Topaín) has made the development of cultivation and grazing areas possible.

Our project is focused on three sites: Turi, Topaín and Paniri, locally known as pukaras (prehispanic hilltop fortified settlements), although fortification is not equally obvious in all three cases. Turi was a densely occupied residential center adjacent to a vega or wetland that was likely important for grazing. Topaín and Paniri were sites with smaller settlements, but with relatively large irrigation and field systems of ca. 25 ha each (Figure 2, Parcero-Oubiña et al., 2012, 2013, 2014, 2015a). Previous research in the area framed the first occupation of the three sites in the Late Intermediate Period (LIP), between ca. 950 and 1400 AD (Le Paige, 1957, Pollard, 1971, Castro et al., 1984, Aldunate et al., 1986, Aldunate, 1993, Aliende et al., 1993, Urbina, 2007, 2010, Malim, 2009). Occupation in both Turi and Paniri continued following the Inka conquest, when Turi became a relevant place for the organization of the Inka rule in the area (Castro and Cornejo, 1990, Cornejo, 1990, Varela et al., 1991, Castro et al., 1993, Aldunate, 1993). Although it is possible that Topaín was also occupied after the Inka conquest, the evidence about that is rather scarce.

Broadly speaking, the LIP was a period of decentralization and emergence of local chiefdoms (Schiapaccasse et al., 1989). Nowadays, a lively debate exists on how to better describe those communities between the proponents of strong social inequalities (Urib,e 2006) and those who argue for models closer to corporate communities, albeit in different ways (Nielsen, 2006, Acuto, 2007). The debate also affects the discussion of the impact of Inka rule (Acuto, 2012), in which temporal resolution is not a minor issue. Traditionally, Inka occupation in this area is considered to have lasted for only 70-80 years, from ca. 1450 until the Spanish conquest in 1532, although 
an earlier period of "Inka influence" has been suggested to happen since ca. 1370-80 (a recent review in Cornejo, 2014).

After the Spanish conquest, most of the population was aggregated at other existing or newly created settlements in the area. From here, local communities organized a system of complementary access to different productive niches, most notably the vega of Turi, used mostly as a fresh pasture reserve. Both the settlement and fields at Topaín seem to have been completely abandoned. Turi was also abandoned, although human settlement has continued in the surroundings up to the present day in the form of a few small ranches. Regarding Paniri, there is also a small historic and modern settlement at the site, and although most of the fields were also abandoned following the Spanish conquest, a section (closest to the canal intakes) continues to be cultivated today. As this paper focuses on the analysis of the cultivation areas, we will be addressing the archaeology of Topaín and Paniri in the remainder of this discussion (Figure 2).

\section{Material and methods}

\subsection{Starting at the ground: limitations of a field approach}

In a preliminary visit to the study area before our first formal field season we identified three characteristics that informed our subsequent research design, all of which had been recognized in previous descriptions of these sites (e.g. Le Paige, 1957, Pollard, 1971, Santoro et al., 1998, Urbina, 2007):

1. The existence of three principle cultivation areas (Figure 2). Two are at Topaín: one extends across the slopes of Cerro Topaín, beneath the pukara (hereafter Topaín-cerro) and the other along a quebrada roughly $500 \mathrm{~m}$. to the east of the cerro (hereafter TopaínR2). The third space is located in the area of Paniri, approximately $4 \mathrm{~km}$. to the east of 
Topaín and surrounding what has been considered another pukara. The first two spaces, in Topaín were irrigated by an extensive and complex network of canals, that originated in the same, now dry, spring. The canals are highly visible today due to the thick travertine deposits that accumulated during their use (Figure 3). In Paniri, the canal network was not as clearly defined, but a large area was also cultivated and the agricultural landscape was more extensive, varied, and complex in comparison to the simple terraces at Topaín.

2. The great morphological complexity of many of the elements that comprise these spaces. For example, from the ground it is difficult to make sense of the numerous, often crisscrossing and discontinuous canal beds at Topaín and their relationship with other archaeological features. The environmental conditions of the area impeded the formation of soils over the remains of the ancient sites, so most of the pre-Inka features are still perfectly visible on the ground today. On the one hand, this meant that we had nearly as much information as could be gathered in any temperate or tropical region through extensive excavation or geophysical prospection. But, on the other hand, it meant that we had a whole lot of evidence to be mapped and documented.

3. The high surface visibility of the majority of elements that comprise these spaces. The environmental conditions of the area impeded the formation of soils over the remains of the ancient sites, so most of the pre-Inka features are still perfectly visible on the ground today. On the one hand, this meant that we had nearly as much information as we could be gathered in any temperate or tropical region through extensive excavation or geophysical prospection. But, on the other hand, it meant that we had an abundance of evidence to be mapped and documented. Canals, walls bordering fields, corrals, 
structures, etc. are in general highly visible at the surface, though the naturally rocky ground surface sometimes made it difficult to discern these features (Figure 4). From an elevated position, they are more apparent (Figure 5), which led us to adopt techniques to gain an aerial perspective to make sense of these spaces.

\subsection{From the ground to the air}

As in any other field project, the first thing we needed was to build a comprehensive documentation of the available evidence. We started with a "seeing from above" approach, based on the extensive use of satellite images to design, assist and guide the process of field survey. This aerial approach is described in further detail in Parcero-Oubiña et al. 2015b, so we will only present here a brief summary.

We acquired three overlapping GeoEye 1 images, with a spatial resolution of $50 \mathrm{~cm}$. in the panchromatic band, which covered an area that included the three sites under analysis. As we expected, the visibility of the archaeological features in these images is remarkable (Figure 6). Based on the photointerpretation of these images, which was checked in the field, we constructed a complete map of all of the sites, locating and describing with a degree of variable detail, the different field groups, constructions, and archaeological elements. The result of this work is a complete GIS-based spatial database built in 8 field seasons (a total of ca. 20 weeks), with a rather small team (typically 4-6 people for mapping and surveying). At the time of writing this manuscript (Sept 2015) the GIS database includes the location and geometry of over 6,500 individual features (constructions, groups of fields, sections of the canals,...), 3,000 of which

have been individually described and photographed, and around 1,200 objects (fragments of pottery, copper, etc.). 
For some particular areas, the satellite images did not provide detail enough to meet our needs. This was especially noticeable in the settlement areas, where the density of constructions is higher. The production of detailed maps of those areas of settlement was especially relevant for us, to allow the development of different types of architectural, functional and domestic space analyses. Among those, the exploration of issues such as the visual prominence of some specific constructions or areas of the settlements, or the internal patterns of movement, was in demand of detailed and accurate 3D models. To produce a more detailed documentation of those areas, we relied in a combination of low altitude aerial images, taken from a UAV, and photogrammetry (more details of this approach in Parcero-Oubiña et al., 2015c).

This aerial approach allowed us not only to map in detail the three areas of Topaín-cerro, Topaín-R2 and Paniri, but also to obtain some important data to better understand them (Figure 7); first and foremost, they provided an accurate estimation of the extension of the three main sectors of fields: Topaín-cerro (9.5 ha), Topaín R2 (25 ha) and Paniri (25 ha). The original extent of fields in Paniri is probably larger than our estimation, as remains of ancient fields are clearly visible below some of the areas currently under cultivation. The 25 ha correspond to the sectors where ancient structures are still visible on the ground today.

The images have been extremely helpful to understand the arrangement of the canals and acequias and the flow and distribution of water across the fields. They were also very helpful to understand the structure of the fields, the existence of different sectors, attached to each other, and their stratigraphic relationships. This allowed for the development of some hypotheses about the temporality of the system, that were to be tested back on the ground through sampling, the excavation of test pits, radiocarbon dating and the analysis of the differential distribution of pottery across the fields. 


\subsection{Back to the ground}

having built a basic cartography of the different sectors (settlements, fields, canals), subsequent fieldwork was aimed at the injection of some order into the vast series of elements that we had mapped and described. Besides a systematic programme of sampling, archaeological fieldwork consisted of a combination of superficial survey and excavation of small test pits aimed at:

- Ground truthing of the photointerpretation.

- The mapping of small scale elements which are not visible or unclear in the satellite images.

- The documentation of the stratigraphic relationships between the mapped elements, as a way to understand the sequence of construction of the system as a whole.

- The documentation of the constructive morphology of walls, terraces and canals, in order to build up a comparative database which will allow the different forms of construction, indicative of different temporal phases, to be identified.

The combination of the aerial view and the data and observations collected in the field allows us to begin to understand how different sectors of cultivation and irrigation were built and managed.

\subsubsection{An order in the canals}

Although we initially assumed the existence of one single canal network at Topaín, as was previously proposed by Santoro et al. in 1998, there are two main canal networks, both with their intakes in a single spring, but with different patterns of use. Furthermore, both show a degree of internal complexity, made up of multiple sections that branch out and often overlap. Although the linear distance between the origin of the canals (an exhausted spring) and the last of the terraces is around $2.5 \mathrm{~km}$, more than $16 \mathrm{~km}$ of canal sections have been documented, comprising the two networks together and including all the stretches, splits and branches. 
The first, Network 1, carried water from the spring to terraces on Topaín-cerro sector. Far from being a single canal, this network is composed of multiple crisscrossed sections, with numerous branches and frequent overlaps (Figure 8), which indicates a complex sequence of construction, use and abandonment that would have implied successive episodes of planning, remodelling and correction (a more detailed analysis can be found in Parcero-Oubiña et al., 2012, Parcero-Oubiña et al., 2015a). As seen in stratigraphic relationships between the main canals, it had at least four main episodes of modification, during the last of which a dam and reservoir were constructed that would have helped to regularize the flow of water. There are two distribution canals that follow the contours of Cerro Topain, but the relationship between the distribution and main canals is unfortunately unclear due to erosion. We can, however, see that there was remodelling (either to make repairs or slight adjustments in slope) of the distribution canals as well. The distribution canals fed a series of closely spaced, rock-lined laterals, which watered narrow terraces covering an area of $\sim 9$ ha that wrapped around the eastern and south-eastern face of the hill. The close spacing of the laterals and shallow terrace depth is probably related to the low volume of water carried by the canals (itself a function of low water availability); small planting surfaces could more easily be saturated by water from closely spaced canals, which allowed for the most efficient use of limited water.

The area irrigated in Topaín-R2 is nearly three times larger ( 25 ha versus 9.5 ha), and is gently sloped with stone field boundaries and relatively few (and rather poorly preserved) terraces. Canal network in Topaín-R2 appears to have been built in one shot: it consists of a single main driving canal from which a series of secondary branches derive, which distribute the water among terraces located on both sides of the quebrada. The main canal parallels the Inka road. 
In association with the main canal and the Inka road a series of constructions which would have been related to agricultural work have been documented. They are small and dispersed, occasionally with later (historic period) pottery. They are located in strategic positions along the network: near splits or branches, with visibility over groups of fields and the Inka road. Similar constructions scattered around the fields were also documented in the Topaín-cerro sector, but they are much more numerous and widely distributed in Topaín-R2

The differences between canals in Topaín-cerro and R2 can be summarized as follows:

- R2 is based on a single large main canal of solid structure which runs rather straight in parallel to the Inka road

- R2 shows little evidence of remodelling or changes, with only some minor overlapping or crisscrossing. A good measure of that difference is the comparison of the ratio between the linear distance comprised by both networks, from the origin to the end, and the total length of canal sections documented: for Topaín-cerro the ratio is 4 (10 km of canals in 2.5 linear $\mathrm{km}$ ), for $\mathrm{R} 2$ the ratio is 3 (6 $\mathrm{km}$ of canals for 2 linear $\mathrm{km}$.).

- While the current appearance of Topaín-cerro corresponds to a complex sequence of episodes, R2 seems to have been designed and built in a single time period, without major remodelling over time.

- There is a difference in the size and amount of infrastructural work associated with both networks. In addition to the canals and dams, also documented in Topaín-cerro, R2 made use of at least 10 aqueducts to cross the quebrada. Although they varied in size, some would have been around $20 \mathrm{~m}$ in length and over $3 \mathrm{~m}$ in height (Parcero-Oubiña et al., 2012). They were used to drive the water across the fields to portions of terrain located 
beyond the slopes of the first quebrada, allowing the terrain around at least 4 different quebradas to be cultivated (Figure 9).

In the case of Paniri, our knowledge of the irrigation network is less complete, resulting in gaps in our map (Figure 10). At Paniri, the water is less carbonate rich and we do not have the thick travertine deposits that characterize the better preserved Topaín canals (see Figure 3). We have documented three water sources (springs or reservoirs) that feed at least three separate irrigation systems. The first is the least extensive, and waters a group of fields located in the north. The second is larger, and waters a vast group of fields situated towards the east of the quebrada principal of Paniri. This second network is composed of a principle canal that splits into two major branches at the pukara de Paniri (see section 4.2.2). Finally, the third network of canals irrigates the fields located to the west of the main quebrada, some of which show evidence of having been cultivated in historic times.

In contrast to what is observed at Topaín, at Paniri we have not to date detected differences in the design of the three canal networks, nor clear differences in the design of the fields that were irrigated by each network. For that reason, we provisionally treat Paniri as a single sector representing a single construction event.

\subsubsection{An order in the fields}

At a smaller scale, there are some obvious differences between the fields in Paniri and both sectors in Topaín. The most striking difference is the existence of a particular type of feature in Paniri, the so-called rumimoqos: mounds with carefully constructed stone retaining walls, and a rocky or mixed rock and earthen fill. There are over 350 at the site, located within the cultivation fields. They are rather varied in shape, length and width, but their typical height ranges between 1.5 and $2.5 \mathrm{~m}$. While they no doubt resulted from clearing the rocky soil, their careful 
construction suggest that they may have had other functions related perhaps to water distribution (as suggested in Aliende et al., 1993, Malim, 2009), protection from wind, and temperature regulation (e.g., retaining heat during the day and releasing it at night, and/or directing or diverting cold air as it flowed downslope) as suggested for similar features in Coctaca, an Inka agricultural system located in Northwestern Argentina (Albeck, 1993, Nielsen, 1994). However, these are all hypothesis that still remain to be tested in depth. There are no local precedents for rumimoqos in the region; stones cleared from the Topaín-cerro terraces were piled up (without retaining walls), primarily at the base of the hill where they were not occupying space that could be cultivated (Figure 12). We still do not know if the rumimoqos were a local invention or whether they might have been introduced by altiplanic populations during the LIP (Castro et al., 1984) or by the Inkas during the Late Period (ca. 1400 - 1540 AD), when the empire could have brought in workers or planners from afar. In any case, the presence of the rumimoqos makes a clear difference in Paniri with respect to both sectors in Topaín, where they are absent, and whatever their function might have been, they suggest a different technology of land cultivation and management.

At a larger scale, when mapping the Topaín-cerro terraces, we noted that there were differences in the construction material and styles of sections of terrace walls. They differ in terms of the type and size of the constructive materials of retaining walls, the finishing of the walls, the use or not of wedges or earth to fill the holes in the walls and the changing pattern of alternation between dividing walls / acequias (irrigation ditches) between the fields (Figure 11, more details can be found in Parcero-Oubiña et al., 2012). This led us to the development of a detailed morphological analysis that resulted in the identification of thirteen different groups (Figure 12). While some of these differences might be just due to available building material, when taken 
together they point to intentional factors: we might be seeing the growth of the system through time, where later people had different building techniques than earlier people; or it might be that the sections (or at least some of them) were built at the same time, with different technological styles representing different social subdivisions.

To date, we have not recorded similar construction differences in Paniri. However, as opposed to the mostly continuous sectors of Topaín, fields in Paniri are somewhat divided into areas delimited by walls or linear rumimoqos (Figure 7). Although physical division is by no means strict, it is reinforced by the changing orientation and layout of the fields. That makes it possible to identify different groups of fields at Paniri as well. The identified field groups were then used to structure a systematic surface collection of pottery, to further examine the development and use of the cultivated areas at Paniri and Topaín, across space and time.

\subsection{Designing a sampling survey}

Previous research at the sites of Paniri and Topaín included systematic surface collections at the habitational areas of both sites, which led to preliminary conclusions on the chronology of these sites (Uribe and Sanhueza, 2000). However, there are also abundant pottery sherds on the agricultural fields, which can provide a complementary picture on the chronology and use of these systems.

Given the great extent of the fields, a 100\% surface sherd collection would have been unfeasible. An estimate based on the direct measurement of 111 individual, bordered plots (i.e, cleared area demarcated by stone alignments or walls, such as front and back terrace risers and the canals that fed or drained each surface) indicates that the average size is $6.54 \mathrm{~m}^{2}$ (see Figure 7). When applied to the total cultivated area of 60 ha, the approximate number of individual plots is 90,000. As an alternative to a full coverage sherd collection, we designed a random stratified 
sample of individual plots for surface pottery collection, which allowed us to obtain a statistically representative perspective on the different cultivation sectors. In most archaeological contexts, implementing this kind of sampling can be time consuming, since it requires defining and locating artificial units (e.g., randomly selected grid squares or transects) in the field in open or continuous spaces. In our case, we took advantage of the well-defined and demarcated individual plots as our sampling and collection units.

To define the sample, we began with the available information on the location, extent, and hypothetical subdivision of the three cultivation zones (Topaín-cerro, Topaín-R2 and Paniri). For the terraces of Topaín-cerro, each of the groups defined by construction style described in the preceding section was used as a single sampling stratum. For Topaín-R2 and Paniri, we have not yet done a similar analysis of construction styles, but instead relied on other criteria to define sampling strata:

- Spatial discontinuity (groups of fields separated by uncultivated areas);

- Constructive elements (walls, linear rumimoqos) that divided one area from another (as in Figure 13);

- Association of cultivated spaces with different canal branches (as in Figure 9).

Using these criteria, 13 sectors (sampling strata) were defined for Topaín-cerro, 17 in Topaín-R2, and 27 in Paniri (Figure 14, Table 1).

Once the strata were defined, we needed to estimate the number of sampling units (individual plots) that existed in each stratum to be able to determine the minimum size of the sample. As mentioned above, we had previously measured 111 individual plots in the field across the sectors. The mean plot size was $6.54 \mathrm{~m}^{2}$ with a median size of $6.45 \mathrm{~m}^{2}$ and a Gaussian-like size distribution with a standard deviation of $1.06 \mathrm{~m}^{2}$. To avoid the risk of underestimation, we 
decided to use a lower value for the reference plot size (mean $-2 x D T)$, which results in an area close to the minimum size documented for the 111 measured plots $\left(4.43 \mathrm{~m}^{2}\right)$. In this way, we ensured that we were not underestimating the number of individual plots in each sector, which would especially affect very small sectors.

With this determination, we could calculate the maximum number of individual plots that existed in each one of the defined strata (Table 2). These figures could then be used to determine the quantity of plots that constituted a statistically significant sample in each stratum. The calculation that we made, following Banning (2002) established our margins of confidence with the following values: confidence level of $95 \%\left(\mathrm{t}^{2}=1.96\right)$, expected proportion $\mathrm{p}=0.5$ and $\mathrm{d}=0.05$. In addition, we applied a finite population correction (Banning, 2002: 126), given the small number of collection units (plots) in some of our strata.

As can be seen in Table 2, the quantity of units to sample per stratum varied between 1 and 64 . The total number of plots in the sample (last column) is 80 in Topaín-cerro, 169 in Topaín-R2 and 139 in Paniri.

Finally, the selection of which specific plots to collect was made by simply distributing in the GIS the established quantity of random points in each one of the subsectors, with a minimum distance between points of 4 meters, to avoid the possibility of more than one point falling in the same individual plot. The results can be seen in Figure 15.

\section{Results}

At the moment, the materials collected during the sampling survey are still being analyzed at the Universidad de Chile, with the goal of defining and quantifying types and forms, and their distribution across sites to make inferences about chronology and past activities. A preliminary 
quantitative approach to the number of sherds collected across the fields, and their spatial distribution, already allows us to propose some preliminary hypotheses and interpretations.

\subsection{Comparison of the three main sectors}

By simply examining the number of fragments collected on the fields, some obvious differences are visible. The high number of fields with no fragments in Topaín-R2 is perhaps the most striking result (Figure 16). To account for the unequal size of the sample in each area, we can also examine the percentage of fields in each sector by the number of recovered sherds (Figure 17). Here, the results are similar: in Topaín-R2 56.2\% of the surveyed fields (95 of 169) had no sherds, compared to $21.8 \%$ in Topaín-cerro (17 of 78) and only 10.1\% (15 of 148) in Paniri. In addition to the disparities in terms of presence/absence, Topaín-R2 is the sector with the lowest density of materials, with a scarcity of plots with high concentrations: only $6.5 \%$ of the fields of Topaín-R2 have more than 5 ceramic fragments compared to 20.5\% at Topaín-cerro and 31.1\% at Paniri.

The results suggest three possible explanations:

- That there is a different surface visibility of pottery due to postdepositional factors

- That there were different original patterns of discard in Topaín-R2

- That there was a different duration in the use of the soil in this sector

The first explanation is highly unlikely, based on geomorphological studies carried out within the project by Huckleberry (2015), which demonstrate that while erosional and depositional processes varied across the study area, they were not of sufficient magnitude to explain the differential burial of Topaín-R2 surfaces in comparison with Topaín-cerro and Paniri. Other factors must explain the lower density of Topaín-R2 materials, either differences in depositional patterns or differences in duration of use. 
To evaluate the other two proposed explanations, we consider the available evidence for the dates of the three sectors. Dating of the study sites has been a primary concern of the project since its inception, but also one of the most methodologically challenging tasks for a project focused on changes across a fairly narrow time range spanning the $11^{\text {th }}$ to early $16^{\text {th }}$ Centuries. The potentially low precision of radiocarbon dates is particularly problematic when trying to assess the effects of Inka incorporation, during a period which only lasted a little over 100 years. In addition, agricultural and irrigation features are notoriously challenging to precisely date. In the case of fields, the relation between organic elements (seeds, charcoal, wood, bone) and the original contexts of deposition is problematic: fields may be used over centuries, with soils mixed through activities such as planting, plowing, weeding, and harvesting. In the case of canals with carbonate-rich water, dates from organic matter derived from aquatic organisms in canal deposits may be affected by the freshwater reservoir effect.

Keeping these problems in mind, to date we have a total of 21 radiocarbon dates: 8 from Topaíncerro, 5 from Topaín-R2, and 8 from Paniri (Table 3). The majority of the dates are from charcoal fragments located in agricultural fields, within canal deposits, or in habitation contexts associated with the fields. In some cases, the organic fraction of sediments from fields were dated (though these would also risk being affected by the ancient carbon present in irrigation water).

Several observations relevant to the present discussion can be made. First, both Topaín irrigation networks (Topaín-cerro and Topaín-R2) were in use simultaneously and for the same duration of time, at least at this timescale (Figure 18), and therefore a chronological explanation for the different concentrations of sherds in the two areas at present seems unlikely, though we are currently dating more samples to refine our understanding of the creation, use, and abandonment 
of the two Topaín irrigation networks. The evidence to date suggests that the moments of greatest activity in the zone take place between 1300 and $1450 \mathrm{cal} \mathrm{AD}$, with some indications that there was an earlier period of use $\left(8^{\text {th }}-10^{\text {th }}\right.$ Centuries $)$ though it should be noted that all of the earlier dates come from organic matter from sediments or from charcoal from canals, which may be skewed by the freshwater reservoir effect; the five early dates should therefore be considered with caution.

In contrast to Topaín, the current dates from Paniri tend to be later than those of any sector in Topaín, with the oldest dating to ca. 1400 AD. The dates also indicate a continued occupation into the historic period of the residential sector and nearby fields that is consistent with other evidence from the site. We do not yet have radiocarbon dates from fields that are more distant from the residential sector, but pottery styles suggest a solely prehispanic occupation, which included the Inka period. Inka period pottery was also identified in the residential sector (Uribe and Sanhueza, 2001), consistent with the radiocarbon dates for this area.

Having rejected the first two possible explanations (differences in post-depositional processes or duration of use) based on the evidence to date, we are left with the third: that the differences in sherd concentrations result from different depositional activities. A review of the spatial distribution of pottery in Topaín R2 (Figure 19) reveals that the areas with the highest density of sherds are either associated with dispersed constructions (corrals, domestic architecture, see Figure 2) along the main canal and or with historic period structures at the south end of the sector; pottery is associated with the occupation of these structures. In contrast, the fields surrounding the structures have little or no pottery. The contrast with Topaín-cerro (Figure 19) and Paniri (Figure 21) is evident. In both cases, pottery was both more abundant and more homogenously distributed (with the exceptions mentioned in the next section). 
With this evidence, one possible explanation is that different agricultural practices were used in the Topain-R2 fields. For example, if pottery arrived in the fields as part of trash used as compost or fertilizer, the lower concentration of sherds in Topaín-R2 suggests less abundant applications in these fields, perhaps due to differences in soil quality. It is also possible that the duration of use was the same, but intensity differed (linked to different crops and/or different cultivation or irrigation practices). Finally, the social practices of field use (commensal activities, irrigation rituals) may have varied in the three sectors, resulting in different patterns of pottery breakage and deposition. These proposed explanations will be further tested as we date more samples and complete ongoing analyses of soil, botanical remains, and the pottery collected from the three sectors.

\subsection{Insights on the internal design of each sector}

In addition to comparisons between the three sectors, we can also make more fine-scale observations within each sector based on variations in the concentrations of sherds across space, and their associations, that help reveal patterns in construction and use.

\subsubsection{Topaín-cerro}

In this sector, the distribution of sherds across the surface is very uniform, with two notable exceptions (Figure 20). First, there is a single sample where a very high number of sherds were recovered (75, in stratum 7$)$; this could be related to symbolic or ritual events taking place in the surroundings. The field where those 75 sherds were collected is located at the top end of a group of fields, next to one of the major rocky outcrops that punctuate the slopes of the cerro. Some isolated constructions are located on top of that outcrop, containing pottery and fragments of copper mineral, an essential component of prehispanic ritual offerings in this region. 
In contrast, there are plots $(n=17)$ from which no sherds were recovered. Three plots stand out: 1,2, and 12 (location in Figure 12). Although 12 is very small, 1 and 2 are more extensive, but only one sherd was recovered in the 7 plots that were surveyed. Both groups have another commonality: they are associated with a canal that reaches the hill then soon abruptly terminates (Figure 12, Figure 20). This canal, unlike the others, has minimal carbonate deposits, suggesting only a brief period of use. Its stratigraphic position suggests an early design of the network, previous to the construction of two principle branches that irrigated the hillside terraces (ParceroOubiña et al. 2015a). The nearly complete absence of pottery in the fields watered by this canal also supports an interpretation of a brief period of use. Given its position above the two successful branches, it is possible that this initial effort was designed to maximize the area watered and brought under cultivation, but builders (bringing water from the spring, over $1.5 \mathrm{~km}$ away) miscalculated the elevation and slope, resulting in a non- or poorly functioning canal. Subsequent attempts were successful.

\subsection{2 $\underline{\text { Paniri }}$}

As at Topaín-cerro sector, the more abundant fragments recovered at Paniri are rather evenly distributed across the area, especially if we focus on the main sector of fields to the south. The number of individual fields with no pottery collected is just 15 (out of a total of 139 surveyed), and they are spatially concentrated in three areas: the northern, southern and western margins of the sector (Figure 21). It is worth noting the occurrence of fields with 0 or just 1 fragments (which suggests a less intense use) downslope, to the south of the system. This might suggest a progressive extension of the system through time. A fine-grained dating of the system (if possible) could test this hypothesis and help to understand the scale of production in this area. 
In contrast to the low density zones, there is a sector near the centre where an exceptional amount of fragments have been recovered (935 fragments in 8 individual plots). Paniri continued to be occupied in historical and modern times. On the west side of the main quebrada, there is a small modern settlement with associated fields and grazing areas that completely disturbs what was originally an area of ancient fields and canals, traces of which are still visible. Wellpreserved, abandoned ancient fields continue to the east of the quebrada, where the group of structures previously designated as the PIT habitational site (Urbina, 2010) is also found. It is among these structures that the very high concentration of sherds was found. This area is also badly disturbed by a historical and modern occupation, where ancient structures were reoccupied, remodelled or dismantled. An inspection of the structures in one of the 2013 field seasons revealed that almost all of the standing constructions are modern or colonial. In addition, we observed that a good part of these structures were built on top of ancient fields or rumimoqos. This led us to propose that there perhaps had never been an aggregated PIT settlement here, but only isolated structures.

The ceramic collection and a closer inspection of this area has led us to revise this initial interpretation. First, the sheer density of sherds is atypical for agricultural contexts, and the area with the greatest number of sherds corresponds perfectly with the sector that has been traditionally been considered the pukara. Second, a new detailed review of the sector allowed us to map the distribution of mortar and grindstone fragments that have been used as building material in historic structures (Figure 22). The result shows a clear concentration of these fragments in a relatively limited space, surrounded but two principal canals that directed water to the main cultivation area via aqueducts located adjacent to the probable residential zone (Figure 23). 
In sum, our most recent observations support the early idea that an aggregated settlement existed in Paniri, but that only traces of this original occupation are intact below later corrals and domestic structures (Figure 23, Figure 24; far less ancient constructions than those suggested by the site plan proposed in Urbina, 2010). The intense historical reoccupation of the site destroyed or obscured much of the earlier occupation, though fragments of intact deposits can still be found.

The identification of the pukara is further supported by the presence of a massive, though partially dismantled, perimeter wall that encloses the area with the high sherd density, the mortars, and the inferred ancient structures (Figure 23, Figure 25). The NE section of this wall was already designated by Urbina (2010) as the edge of the pukara, although we believe that the remains of walls that separate the sector from the quebrada to the west and northwest are also part of the original settlement.

\section{Discussion}

The results that we have presented in the previous section provide some interesting clues to better understand the processes of construction and use of the fields. The limited precision of the radiocarbon dates does not allow us to explore in full detail some of the hypotheses we propose to understand the differences we found among the fields in terms of morphology, layout and pottery distribution. This justifies the need for further dates, in order to build a comprehensive body of chronological evidence that can give more robust support to some of those ideas. However, at a more general scale, the differences between Paniri and Topaín are clear. The identification of those differences is essentially based on the combined results of the aerial and field survey, and that they are further supported by the radiocarbon dates. 
A qualitative and quantitative analysis of the pottery distribution (identifying different types and forms and their relative frequencies across space) should provide relevant evidence to further evaluate those differences, but the quantification shown in the preceding section already poses some interesting questions, especially in relation to the low number of sherds collected in Topaín-R2. As we have argued, it is likely that the differences relate to distinct activities in the past and processes of original deposition. As long as both sectors in Topaín largely correspond to the same time period (LIP), the introduction of a radically different cultivation technology is a rather unlikely explanation. We can think, basically, of two possibilities. If the patterns of pottery deposition were the same (i.e., the processes through which pottery ends up on the fields), it must be acknowledged that those processes were less frequent in the fields in Topaín-R2. An obvious possibility is that pottery comes as part of rubbish used as fertilizer. In that case, the fields in R2 either needed less manure, were used for different crops, or were cultivated for a shorter time period. We could also think of other kind of processes that brought the pottery to the fields (like social / symbolic events performed at the fields), but those events would have been less frequent in Topaín-R2.

If the patterns of pottery deposition were different in Topaín-R2 than in Topaín-cerro, this would clearly point to a different management and use of those particular fields. As both sectors were built and used in the LIP, those differences might relate to different social/ethnical/kin practices, such as different groups managing each particular sector and performing different practices at the site.

A series of ongoing analyses will certainly shed some new light on some of those hypotheses. For instance, it should be feasible to check the similarity between the physical and compositional properties of the soils to test the "fertilizer hypothesis", or to compare plant remains (phytoliths) 
to test the "different crops hypothesis". Further analysis of the pottery (types and forms and their relative frequencies) will help to explore the "different practices hypothesis".

\section{Conclusions}

In contrast to what is typically observed in more humid temperate or tropical regions of the globe, the archaeological record of deserts such as the Atacama are typically characterized by the abundance and high visibility of remains. Consequently, fieldwork is oriented towards developing methods of creating and managing very large datasets, and of subsequently structuring the data and making it comprehensible.

In recent years, the rapid development of technologies such as GIS, photogrammetry or satellite remote sensing has had a visible effect in archaeology. The risk of "technological fetishism" has often been present in such approaches (Huggett, 2004). In this paper, we have tried to show a case study where technology and tools are part of a problem-oriented research design. Carefully taking into account the research objectives and the characteristics of both the study area and the archaeological record, a specific methodology was designed based on a combination of different sources and approaches. Starting at the ground, moving to the air and returning back to the ground provided a multiscale view of the complex and varied archaeological record of those sites. The aerial view gave us the chance to grasp the general layout of the fields and canals, their scale and their spatial relations, but also to record in great detail the internal arrangement of the fields, canals and other constructions. The field approach recognized formal differences, stratigraphic relationships, and the spatial distribution of features and objects. The main outcome of that combination of aerial and ground based survey was to construct and order a large dataset. In turn, this order provided the basis for developing a series of hypotheses on the origin, use, and 
transformation of irrigation and cultivation spaces, which can be tested through future archaeological work. All of this was accomplished with a relatively modest investment of resources, equipment, and fieldwork.

\section{Acknowledgements}

The authors wish to give very special thanks to the Comunidades Indígenas Atacameñas of Ayquina-Turi and Cupo for allowing us to work in their ancestral places, especially to both the former and current leaders D. René Panire and D. Mario Berna (Ayquina-Turi) and Sara Berna (Cupo). The research presented here was made possible thanks to the financial support from different sources: the Spanish Ministry of Culture (Actuaciones Arqueológicas en el Exterior, calls 2010 to 2013), Comisión Nacional de Investigación Científica y Tecnológica de Chile (CONICYT-USA 2013-0012), Wenner-Gren Foundation for Anthropological Research (International Collaborative Research Grant), National Geographic Society (grant \#9296-13) and National Science Foundation (Catalyzing International Collaborations Grant, award OISE1265816).

We would like to acknowledge the outstanding work carried out by all the colleagues who participated in the fieldwork teams which produced the evidence presented here: Roberto Aboal, Sonia García Rodríguez, Camilo Robles, Rocío Varela, Alejandro Güimil-Fariña, Patricia Mañana-Borrazás, Cristián González, Beau Murphy, Miguel Martínez, Xurxo Ayán, Natalia La Mura and Pablo Méndez Quirós. Mauricio Uribe and Simón Urbina were kind enough to join us for some of the field seasons and to assist us in the reconnaissance of the sites and materials. 


\section{References}

Acuto, F.A., 2007. Fragmentación vs. integración comunal: Repensando el Período Tardío del Noroeste Argentino. Estudios Atacameños 34, 71-95.

Acuto, F.A., 2012. Landscapes of inequality, spectacle and control: Inka social order in provincial contexts. Revista Chilena de Antropología 25, 9-64.

Albeck, M.E., 1993. Contribución al estudio de los sistemas agrícolas prehispánicos de Casabindo. PhD Dissertation. Facultad de Ciencias Naturales y Museo, Universidad Nacional de La Plata.

Aldunate, C., 1993. Arqueología en el Pukara de Turi, XII Congreso de Arqueología Chilena. Boletín Museo Regional de la Araucanía, pp. 61-78.

Aldunate, C., 1999. El dominio del Tawantinsuyu sobre Turi, Tras la huella del Inka en Chile. Museo Chileno de Arte Precolombio/Banco Santiago, Santiago, pp. 38-43.

Aldunate, C., Berenguer, J., Castro, V., Cornejo, L., Martínez, J.L., Sinclaire, C. 1986. Cronología y asentamiento en la región del Loa Superior. Dirección de Investigación y Bibliotecas / U. De Chile, Santiago.

Aldunate, C., Castro, V., Varela, V., 2003. Antes del Inka y después del Inka: paisajes culturales y sacralidad en la Puna de Atacama, Chile. Boletín de Arqueología PUCP 7, 9-26.

Alliende, P., Castro, V., Gajardo, R., 1993. Paniri: un ejemplo de tecnología agrohidráulica. Actas del XII Congreso Nacional de Arqueología 2, 123-128.

Banning, E.B., 2002. Archaeological Survey. Springer. New York.

Berenguer, J., 2007. El camino del Alto Loa y la creación del espacio provincial en Atacama, in Nielsen, A.N, M. C. Rivolta, V. Seldes, M. M. Vázquez and H. R. Mercolli (Eds.), 
Producción y Circulación Prehispánicas de Bienes en el Sur Andino. Editorial Brujas, Córdoba.

Berenguer, J., Cáceres, I., Sanhueza, C., Hernández, P., 2005. El Qhapaqñan en el Alto Loa, norte de Chile: Un estudio micro y macromarfológico. Estudios Atacameños 29, 7-39.

Castro, V., Cornejo, L.E., 1990. Estudios en el Pukara de Turi, Norte de Chile. Gaceta Arqueológica Andina 5, 57-66.

Castro, V., Aldunate, C., Berenguer, J., 1984. Orígenes altiplánicos de la Fase Toconce. Estudios Atacameños 7, 209-235.

Castro, V., Maldonado, F., Vásquez, M., 1993. Arquitectura del Pukara de Turi, XII Congreso Nacional de Arqueología Chilena. Boletín del Museo Regional de la Araucanía, pp. 79106.

Castro, V., Varela, V., Aldunate, C., Araneda, E. 2004. Principios orientadores y metodología para el estudio del Qhapacñan en Atacama: Desde el portezuelo del Inka hasta el río Grande. Chungara 36(2), 463-481.

Cornejo, L., 1990. La molienda en el pukara de Turi. Chungara 24-25, 125-143.

Cornejo, L.E., 1999. Los incas y la construcción del espacio en Turi. Estudios Atacameños 18, $165-176$.

Cornejo, L., 2014. Sobre la cronología de la imposición cuzqueña en Chile. Estudios Atacameños, 101-116.

Huckleberry, G., 2015. Geomorphological Overview of the Topain and Paniri Archaeological Sites, Turi Basin, Northern Chile. Unpublished report.

Huggett, J., 2004. Archaeology and the new technological fetishism. Archeologia e Calcolatori $15,81-92$. 
Le Paige, G., 1958. Antiguas Culturas Atacameñas en la cordillera chilena (II parte). Anales de la Universidad Católica de Valparaíso 4-5.

Llagostera, A., 1976. Hipótesis sobre la expansión incaica en la vertiente occidental de los Andes meridionales, in: Niemeyer, H. (Ed.), Homenaje al Dr. Gustavo Le Paige. Universidad del Norte, Antofagasta, pp. 203-228.

Malim, T., 2009. Tears of the sun: condensation and irrigation in the Andes, in: Nash, G., Gheorghiu, D. (Eds.), The archaeology of people and territoriality. Archaeolingua, Budapest, pp. 116-136.

Nielsen, A.E. 1995. Aportes al Estudio de la Producción Agrícola Inka en la Quebrada de Humahuaca (Jujuy, Argentina). Hombre y Desierto 9, Actas del XIII Congreso Nacional de Arqueología Chilena, Antofagasta, pp. 245-256.

Nielsen, A.E., 2006. Plazas para los antepasados: Descentralización y poder corporativo en las formaciones políticas preincaicas de los Andes circumpuneños. Estudios Atacameños 31, 63-89.

Núñez, L., 1999. Valoración minero-metalúrgica circumpuneña: menas y mineros para el Inka rey. Estudios Atacameños 18, 177-221.

Nuñez, L., Grosjean, M., Cartagena, I., 2005. The expansion of the Inka Empire into the Atacama Desert, in: Smith, M., Hesse, P. (Eds.), $23^{\circ} \mathrm{S}$ : Archaeology and Environmental History of the Southern Deserts. National Museum of Australia Press, Canberra, pp. 324332.

Nuñez, P., 1991. Un canal de regadío incaico: Socaire-Salar de Atacama, Actas del XI Congreso Nacional de Arqueología Chilena, vol 2, pp. 259-267. Temuco. 
Nuñez, P., 1993. Posibilidades agrícolas y población del incario en el área atacameña, norte de Chile, Actas del XII Congreso Nacional de Arqueología Chilena, Temuco, pp. 259-267. Parcero-Oubiña, C., Fábrega-Álvarez, P., García-Rodríguez, S., Meléndez, A.T., Salazar, D., 2012. Paisajes fortificados y agrarios en el altiplano andino. Aproximaciones al pukara de Topaín, Informes y Trabajos del IPCE. Instituto de Patrimonio Cultural de España, Madrid, pp. 22-39.

Parcero-Oubiña, C., Fábrega-Álvarez, P., Ferro-Vázquez, C., Meléndez, A.T., Salazar, D., 2013. Trabajos en torno al pukara de Topaín (segunda región, Chile). Campaña 2011. Informes y Trabajos del IPCE 9, 58-85.

Parcero-Oubiña, C., Fábrega-Álvarez, P., Ferro-Vázquez, C., Meléndez, A.T., Salazar, D., hayashida, F., 2014. Paisajes fortificados en el altiplano andino: nuevos trabajos en torno al Pukara de Topaín (segunda región, Chile). Informes y Trabajos del IPCE 11, 127-144.

Parcero-Oubiña, C., Fábrega-Álvarez, P., Salazar, D., hayashida, F., Borie, C., Pino, M., 2015a. Sistemas Agrohidráulicos de los Períodos Intermedio Tardío y Tardío en el Loa Superior: el caso de Topaín. Boletín de la Sociedad Chilena de Arqueología (in press).

Parcero-Oubiña, C., Fábrega-Álvarez, P., Troncoso, A., Salazar, D., hayashida, F., GüimilFariña, A., Mañana-Borrazás, P., Pino, M., Borie, C., 2015b. Introduciendo orden en el registro mediante tecnologías no destructivas: experiencias en el estudio de paisajes agrarios prehispánicos en la región de Atacama (Norte de Chile), in: Mayoral Herrera, V. (Ed.), Revalorización de zonas arqueológicas mediante el empleo de técnicas no destructivas. CSIC, Madrid (in press).

Parcero-Oubiña, C., Mañana-Borrazás, P., Güimil-Fariña, A., Fábrega-Álvarez, P., Pino, M., Borie, C., 2015c. Empleo de UAV para una documentación efectiva y de bajo coste de 
sistemas agrícolas prehispánicos en el área desértica de Atacama (N. Chile). Boletín de Arqueología PUCP (in press).

Pollard, G. C., 1970. The Cultural Ecology of Ceramic Stage Settlement in the Atacama Desert, Ph.D. dissertation, Dept. of Anthropology, Columbia University.

Salazar, D., 2008. La producción minera de San José del Abra durante el Período Tardío Atacameño. Estudios Atacameños 36, 43-72.

Salazar, D., Berenguer, J., Vega, G., 2013. Paisajes minero-metalúrgicos incaicos en Atacama y el Altiplano Sur de Tarapacá (Norte de Chile). Chungará 45, 83-103.

Santoro, C.M., Nuñez, L., Standen, V.G., González, H., Marquet, P.A., Torres, A., 1998. Proyectos de irrigación y la fertilización del desierto. Estudios Atacameños 16, 321-336.

Schiappacasse, V., Castro, V., Niemeyer, H., 1989. Los desarollos regionales en el Norte Grande (1000 a 1400 d.C.), in: Hidalgo, J., Schiappacasse, V., Niemeyer, H., Aldunate, C., Solimano, I. (Eds.), Culturas de Chile. Prehistoria desde sus orígenes hasta los albores de la conquista, pp: 181-220. Editorial Andres Bello, Santiago.

Urbina, S., 2007. Estudio arquitectónico del pucara de Topaín. Boletín de la Sociedad Chilena de Arqueología 40, 29-46.

Urbina, S., 2010. Asentamiento y arquitectura: historia Prehispánica Tardía de las Quebradas Altas del Río Loa. Actas del XVII Congreso Nacional de Arqueología Chilena, 119-131.

Uribe, M., 1997. La alfarería de Caspana y su relación con la prehistoria tardía de la Subárea Circumpuneña. Estudios Atacameños 14, 243-262.

Uribe, M., 2002. Sobre alfarería, cementerios, fases y procesos durante la prehistoria tardía del desierto de Atacama (800-1600 DC). Estudios Atacameños 22, 7-31. 
Uribe, M., 2006. Acerca de complejidad, desigualdad social y el complejo cultural Pica-Tarapacá en los Andes Centro-Sur (1000-1450 DC). Estudios Atacameños 31, 91-114.

Uribe, M., Sanhueza, L., 2001. Sobre Incas y cerámica en el Desierto de Atacama. Technical report Proyecto Fondecyt 1000148. Manuscript on file. Fondo Nacional de Investigación Científica y Tecnológica, Santiago, Chile.

Uribe, M., Adán, L., Agüero, C., 2002. El dominio del Inka, identidad local y complejidad social en las tierras altas del desierto de Atacama, Norte Grande de Chile (1450-1541 d.C.). Boletín de Arqueología PUCP 6, 301-336.

Varela, V., Uribe, M., Adán, L., 1991. La cerámica arqueológica del sitio "Pukara" de Turi: 02Tu-002. Actas del XII Congreso Nacional de Arqueología Chilena, Temuco. 
Figure 1. Location of the study area and the sites under analysis.

Figure 2. Topaín (left) and Paniri (right): extension of prehispanic fields and constructions, over a composition of bands of a GeoEye 1 image. The denser concentrations of black dots indicate the location of the two pukaras. Intensity of red in the satellite image indicates moisture. Most of the reddish area to the northwest of Paniri is altered by modern cultivation, but it was probably also part of the prehispanic fields.

Figure 3. Travertine-lined canal at Topaín.

Figure 4. The abundance of stones creates a landscape with a rather "messy texture", as in this image of a sector of fields in Paniri. Finding order in the fields and other agricultural structures here seems a challenging task (but see Figure 6 and Figure 7).

Figure 5. With an aerial perspective, the structure of the fields is revealed. View of the sector of fields Topaín-cerro taken from the pukara.

Figure 6. Composition of bands of a GeoEye 1 image showing part of the settlement area and fields in Paniri. At the centre of the image, the same sector shown in Figure 4. From the air it is much easier to understand the general layout of the archaeological elements. Intensity of red indicates moisture

Figure 7. Detail of an orthoimage of a sector of fields in Paniri, produced with low altitude aerial photos taken from a UAV. This is again the same sector shown in Figure 4. At this detail, from the air it is much easier to understand the arrangement of the fields, the changes in their size and orientation, and their spatial relation with other constructions (canals, walls, rumimoqos).

Figure 8. General layout of the Topaín-cerro sector. In the inset, topography of the area. Figure 9. General layout of the Topaí-R2 sector. In the inset, topography of the area. 
Figure 10. General layout of the Paniri sector. In the inset, topography of the area, showing the main quebradas.

Figure 11. Different morphologies of terraces built with large stone blocks in Topaín-cerro.

Figure 12. Morphological groups of terraces identified in the Topaín-cerro sector.

Figure 13. Detail of an orthoimage of an area of fields in Paniri, produced with low altitude

aerial photos taken from a UAV. Walls and linear rumimoqos divide the area, and fields follow different orientations.

Figure 14. Sampling strata defined in the three sectors: (1) Topaín Cerro, (2) Topaín R2 and (3)

Paniri.

Figure 15. Random selection of $\mathrm{n}$ fields to be collected in each sector.

Figure 16. Number of fields with $\mathrm{n}$ sherds in the three sectors.

Figure $17 . \%$ of fields with $\mathrm{n}$ sherds in the three sectors.

Figure 18. Calibrated radiocarbon dates for the three sectors ( $2 \sigma$ calibration, SH Cal 13 curve).

Figure 19. Spatial distribution of number of fragments collected in the two sectors of Topaín.

Figure 20. Distribution of number of fragments collected per stratum in Topaín-cerro.

Figure 21. Spatial distribution of number of fragments collected in Paniri.

Figure 22. Fragment of grinding stone reused in a modern corral.

Figure 23. Evidences of an ancient settlement at Paniri: reused fragments of grinding stones and mortars, and possible remains of ancient constructions. Constructions in grey are modern.

Figure 24. Doorposts of an ancient construction in Paniri.

Figure 25. Remains of the massive wall surrounding the settlement area of Paniri to the west. 
Table 1. Summary of the sampling strata defined in the three sectors.

Table 2. Sample size for each sector and stratum. $\mathrm{N}=$ estimated maximum number of individual fields per sector; $\mathrm{n}=$ sample size, number of fields to be collected.

Table 3. Radiocarbon dates available: context of the samples and results. 


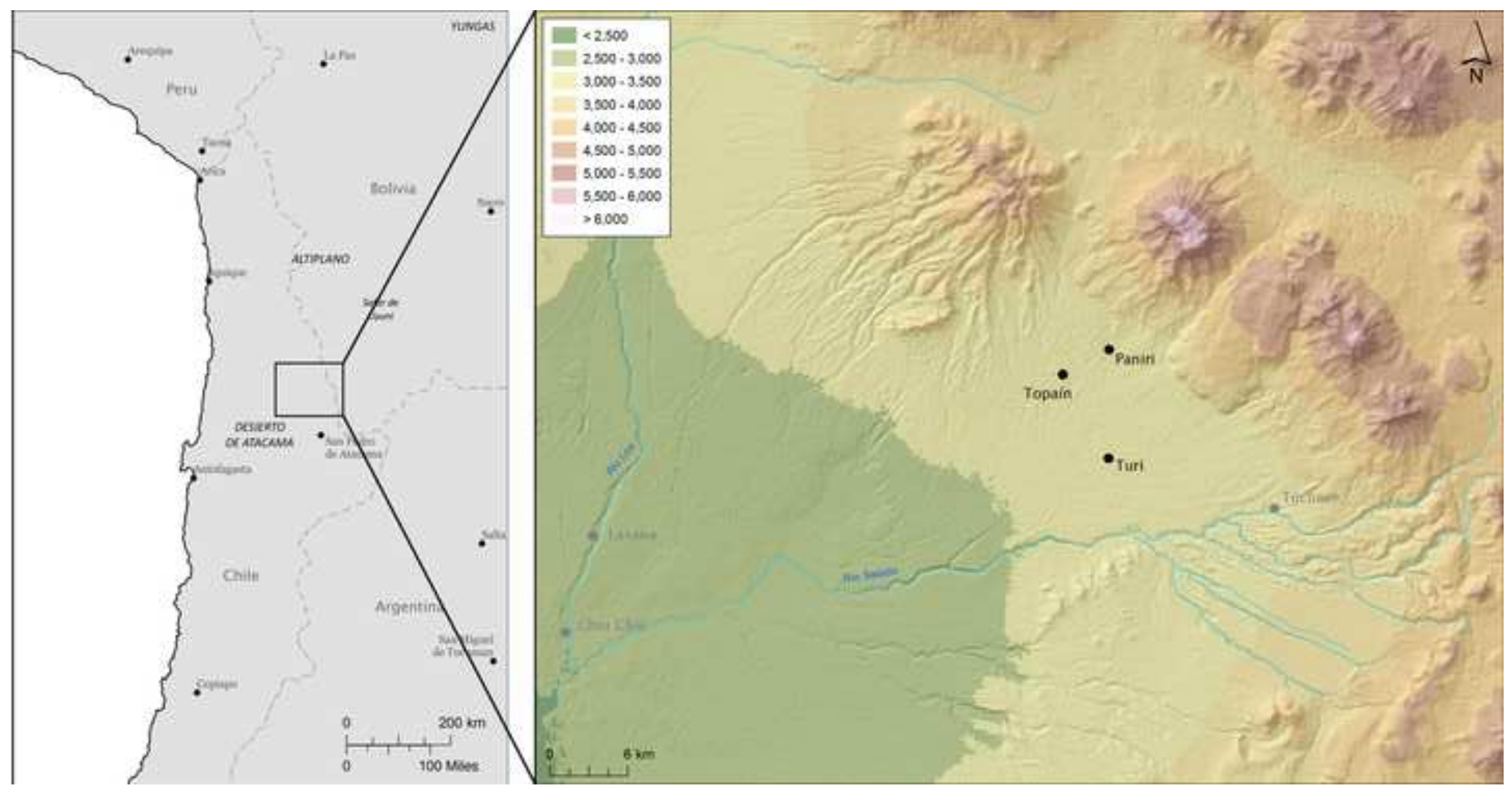




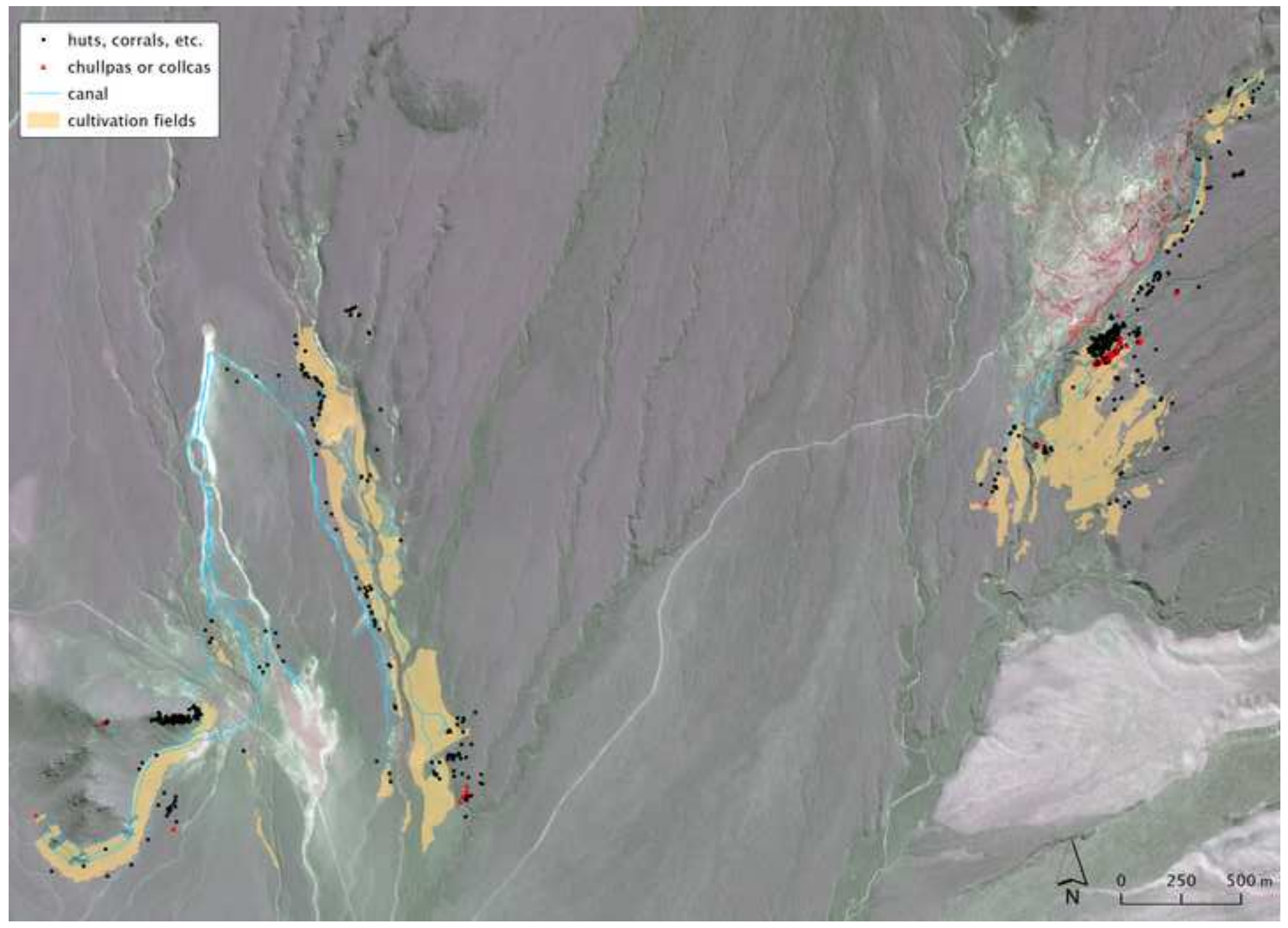




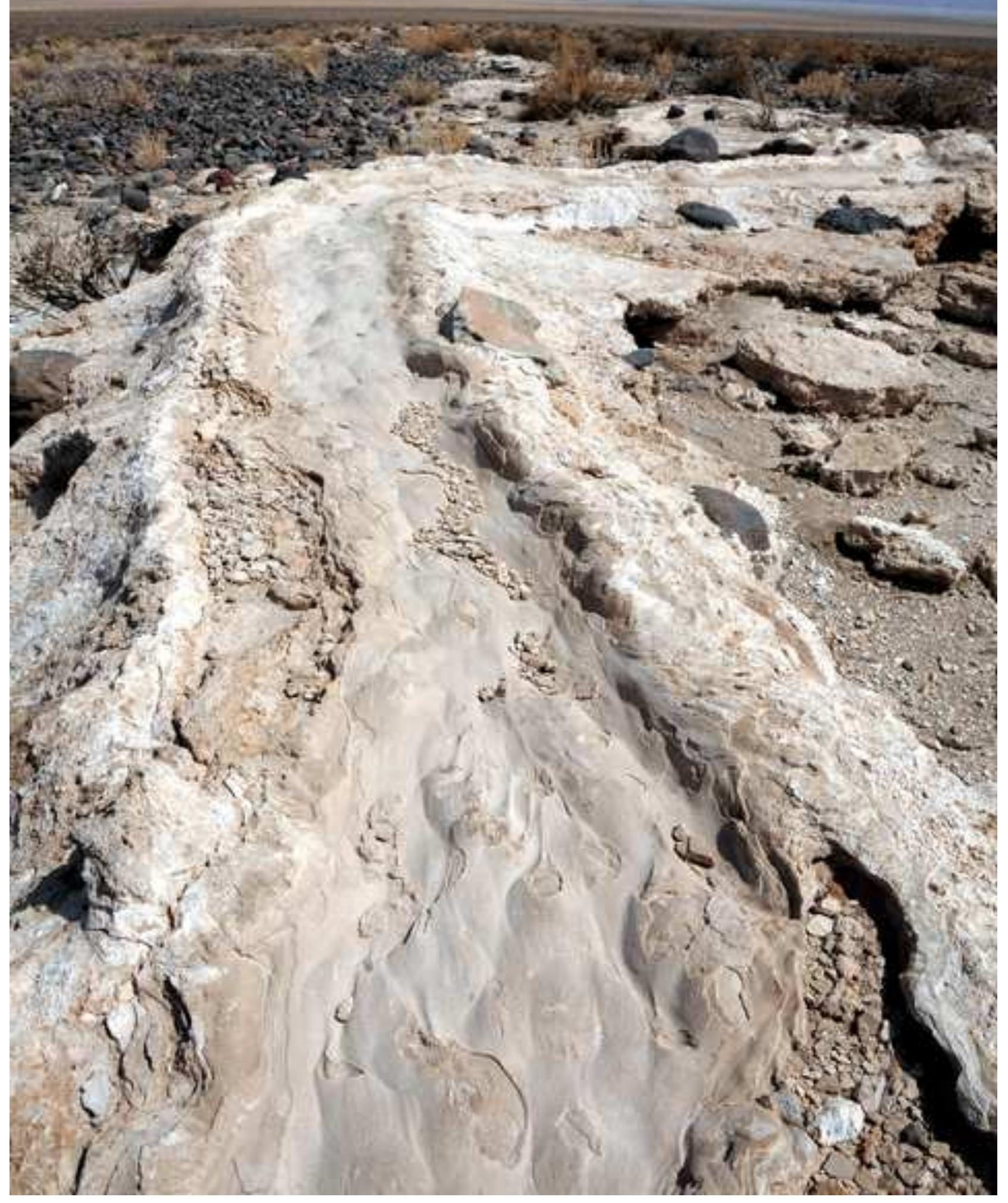




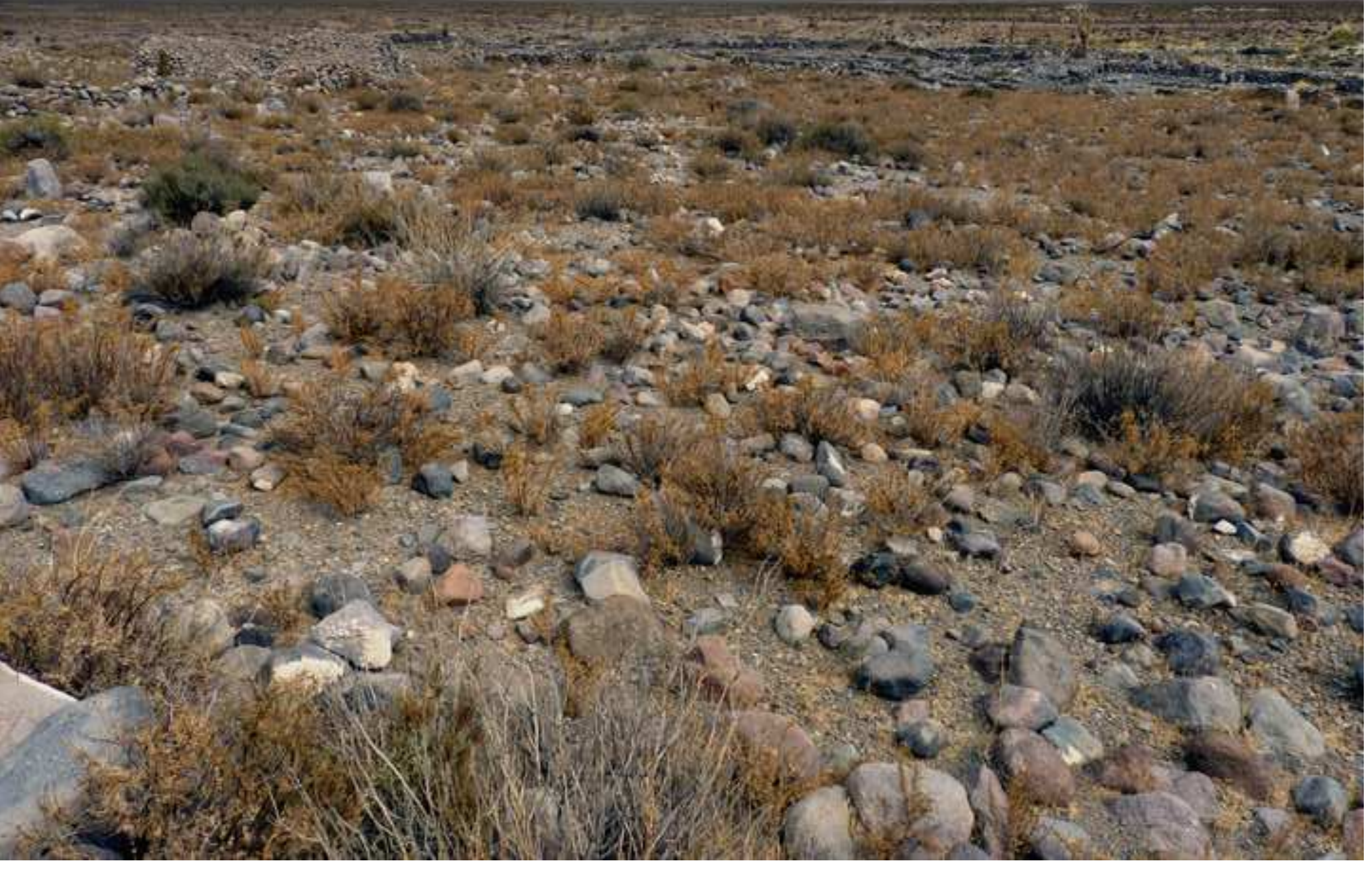




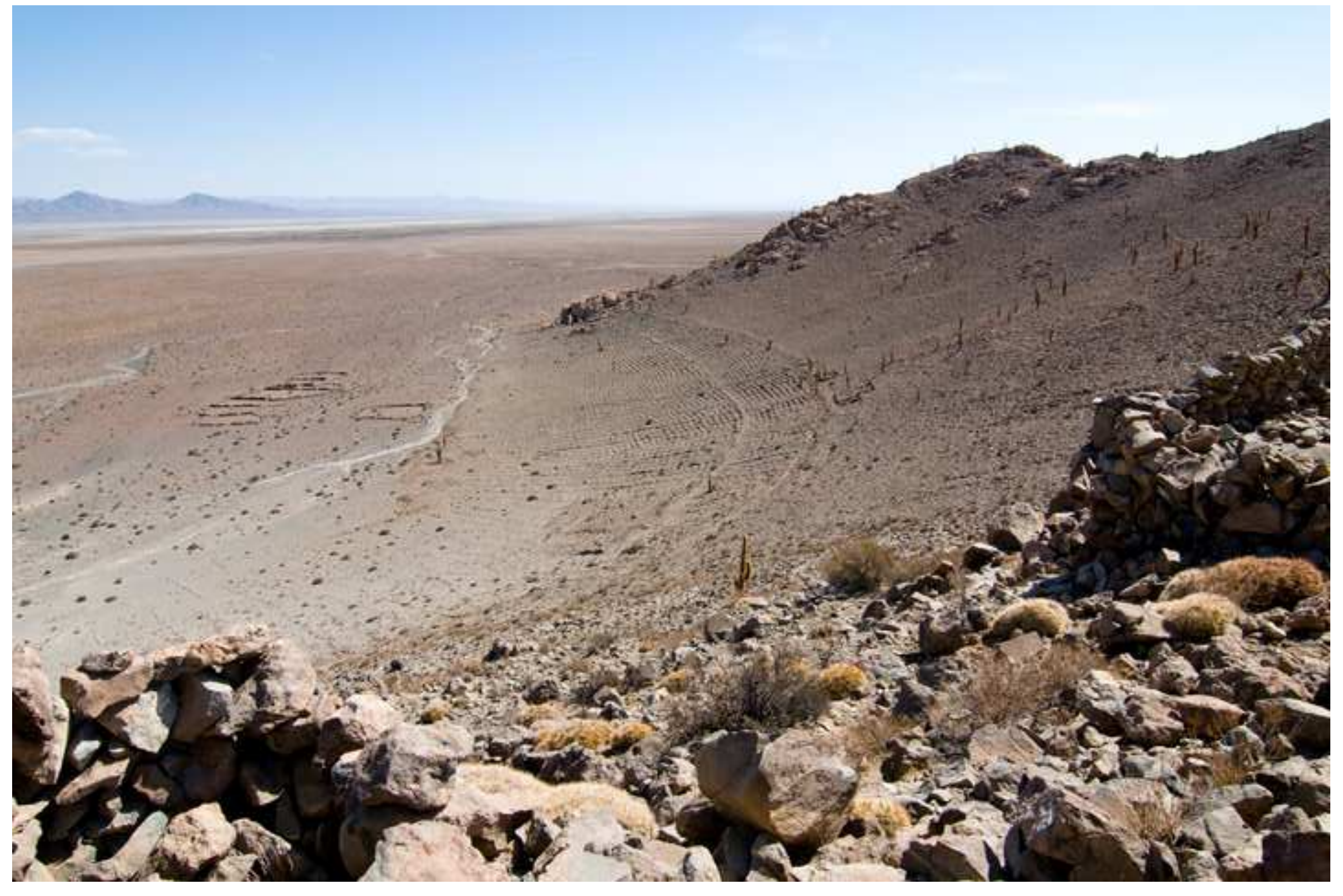




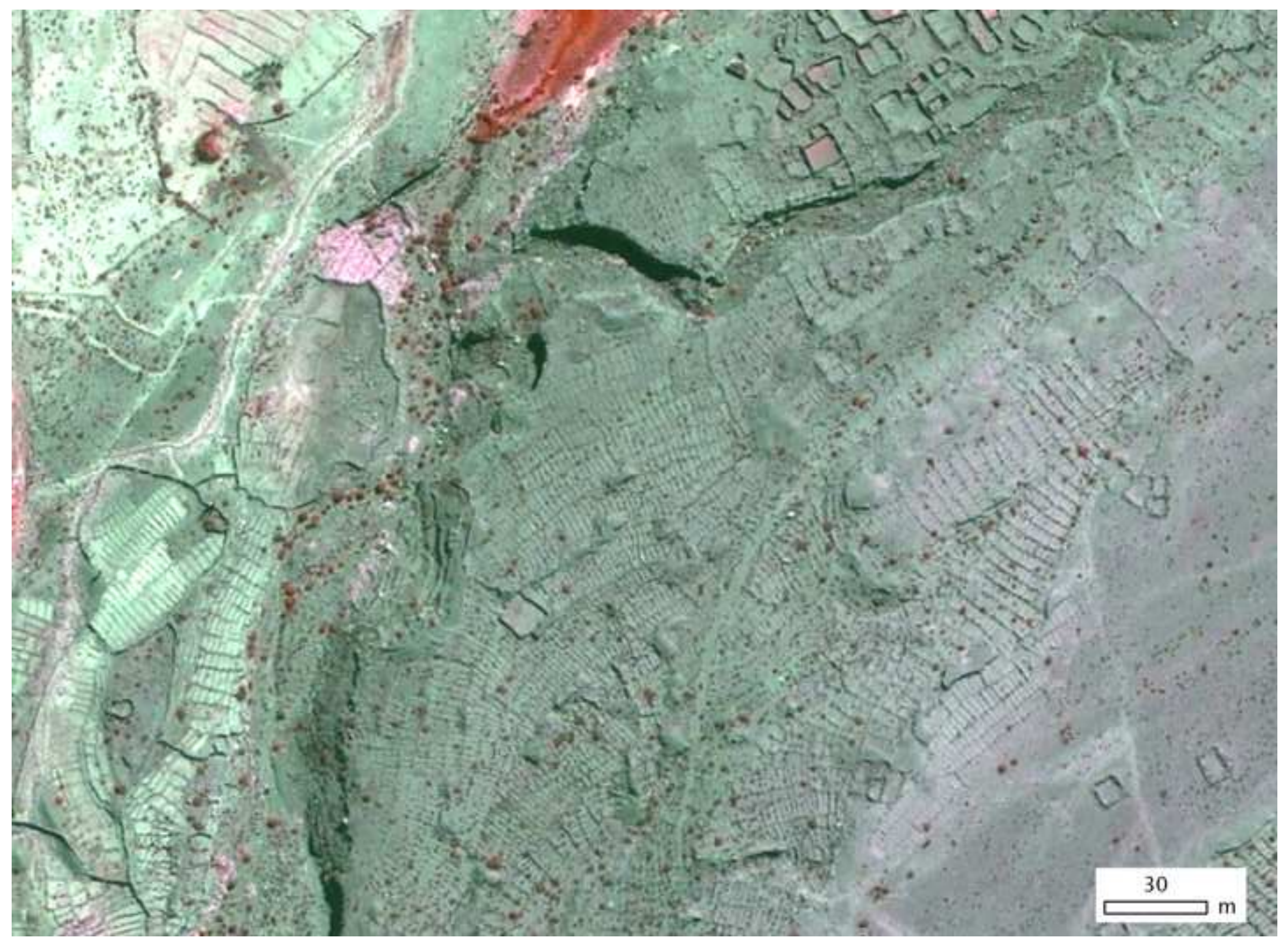




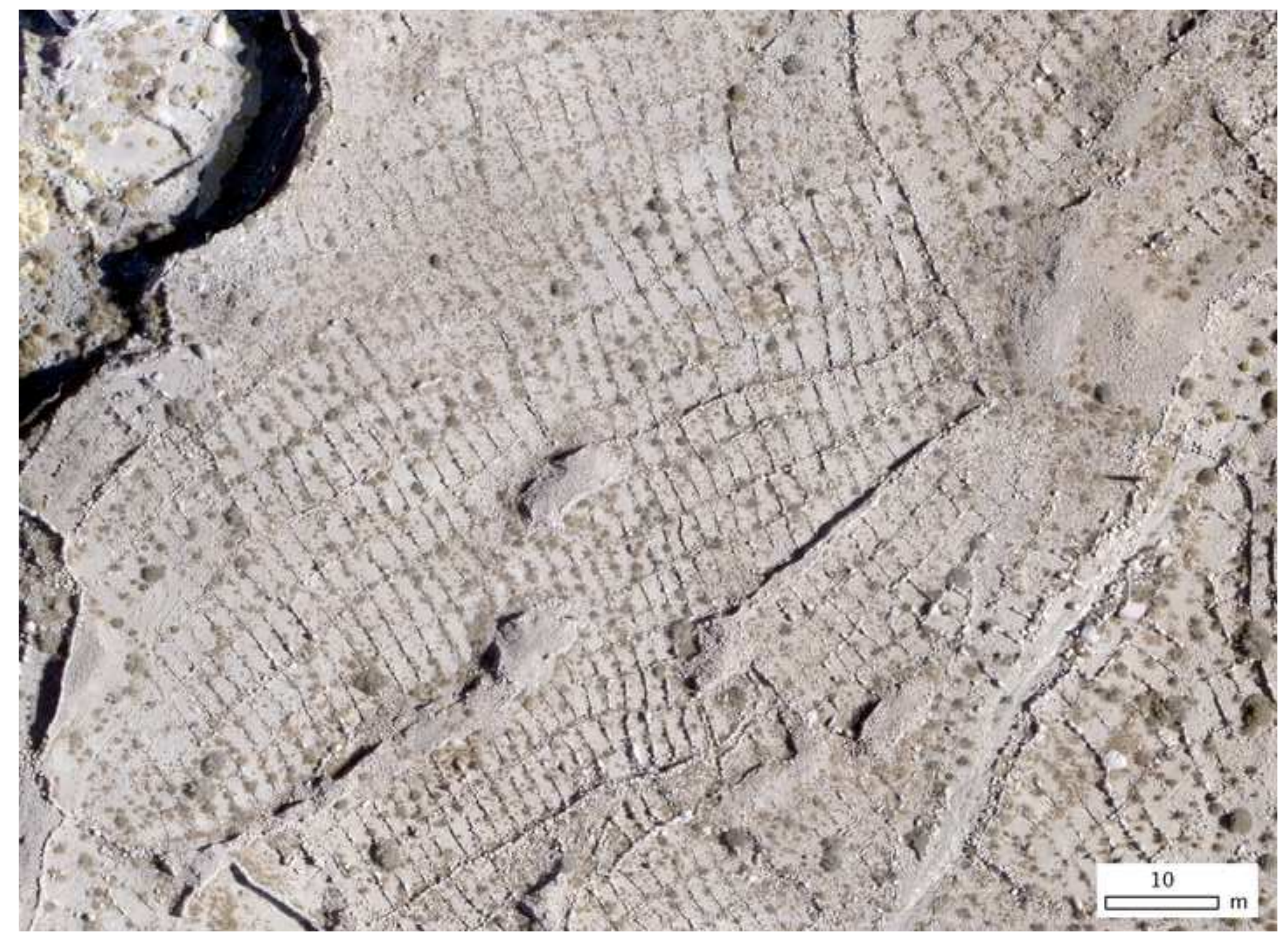



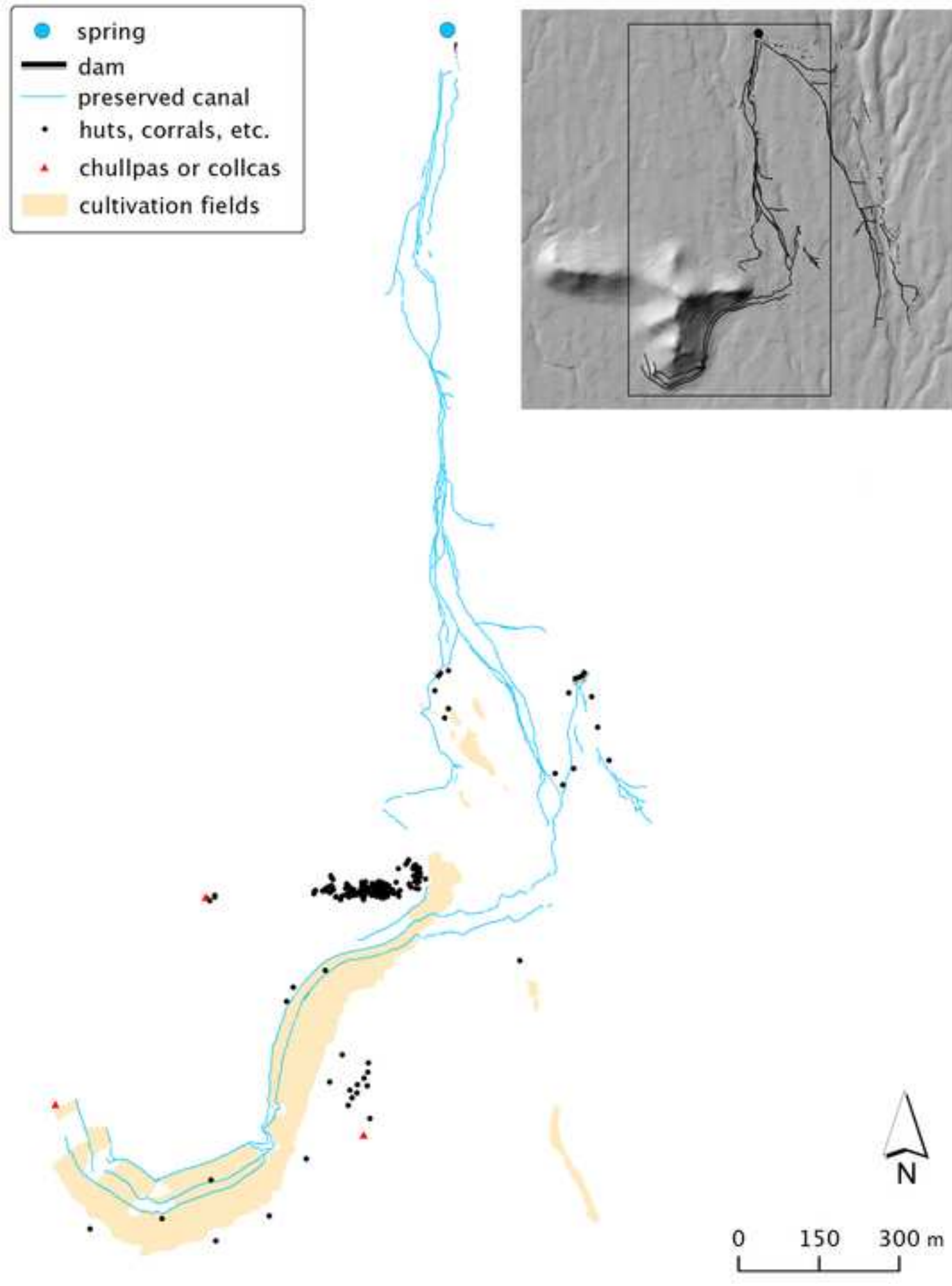


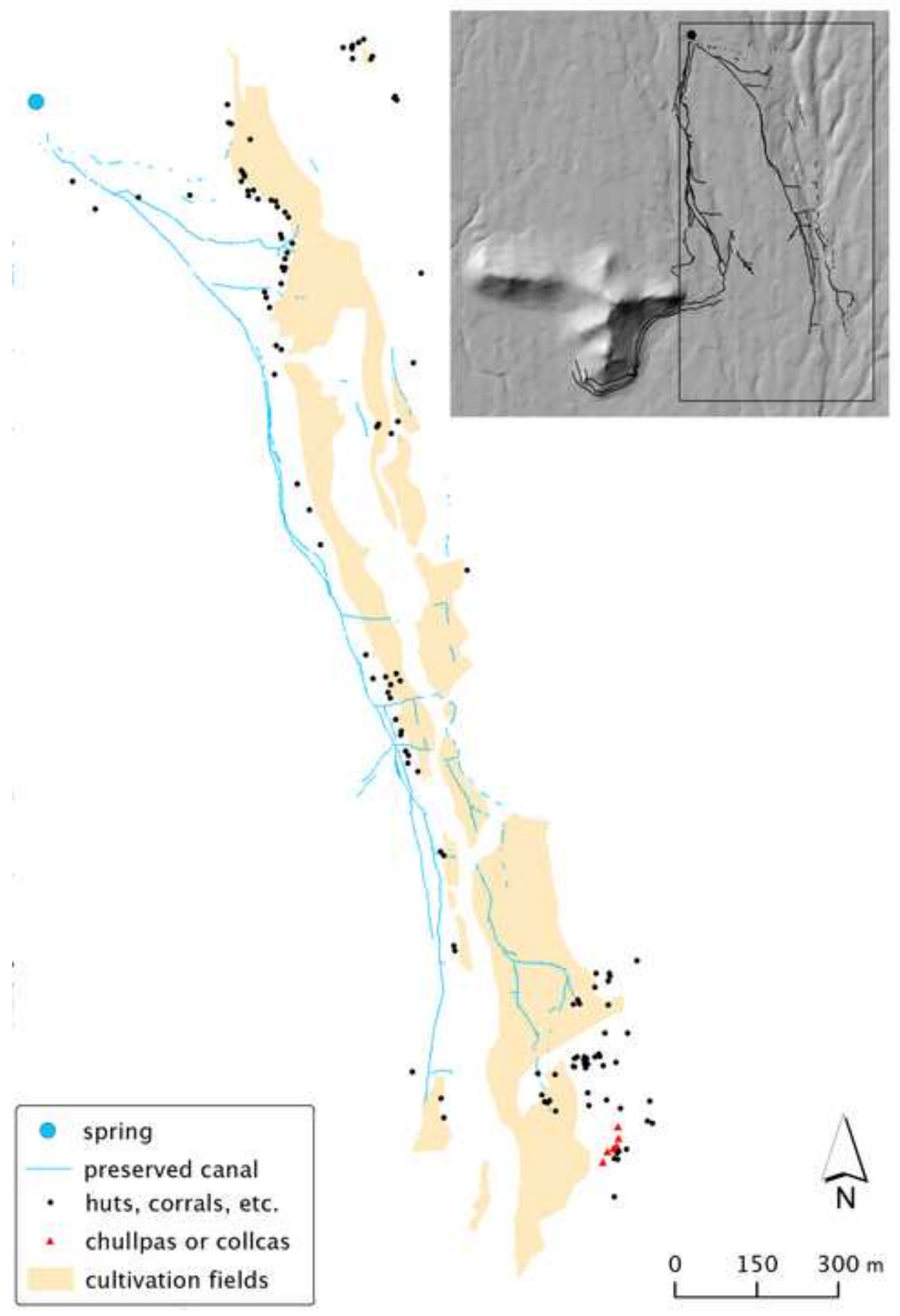




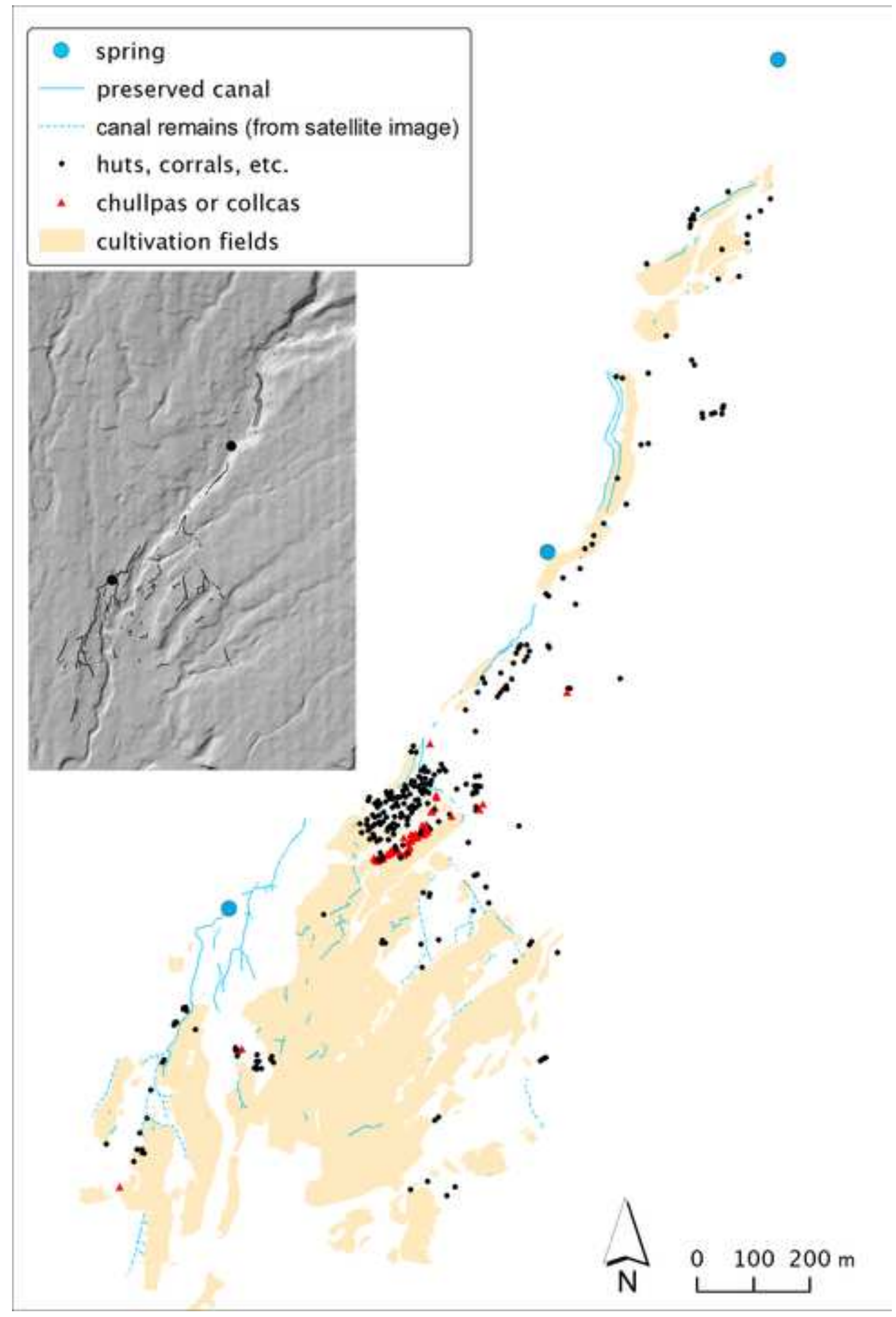




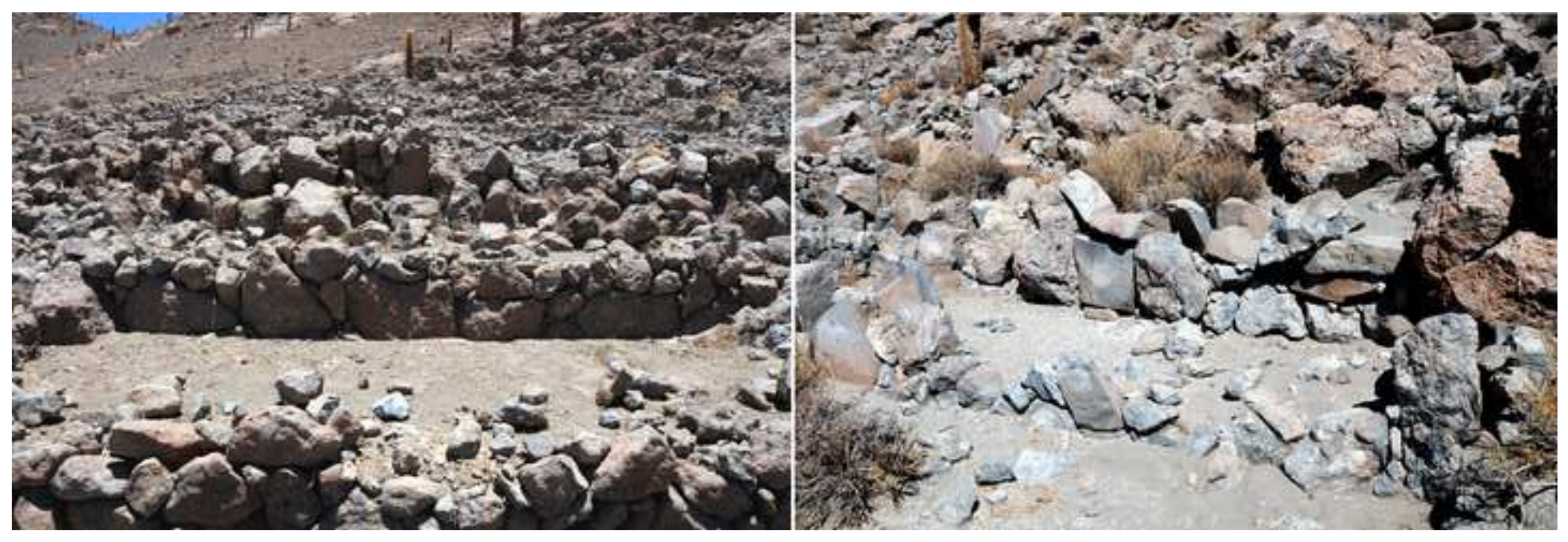




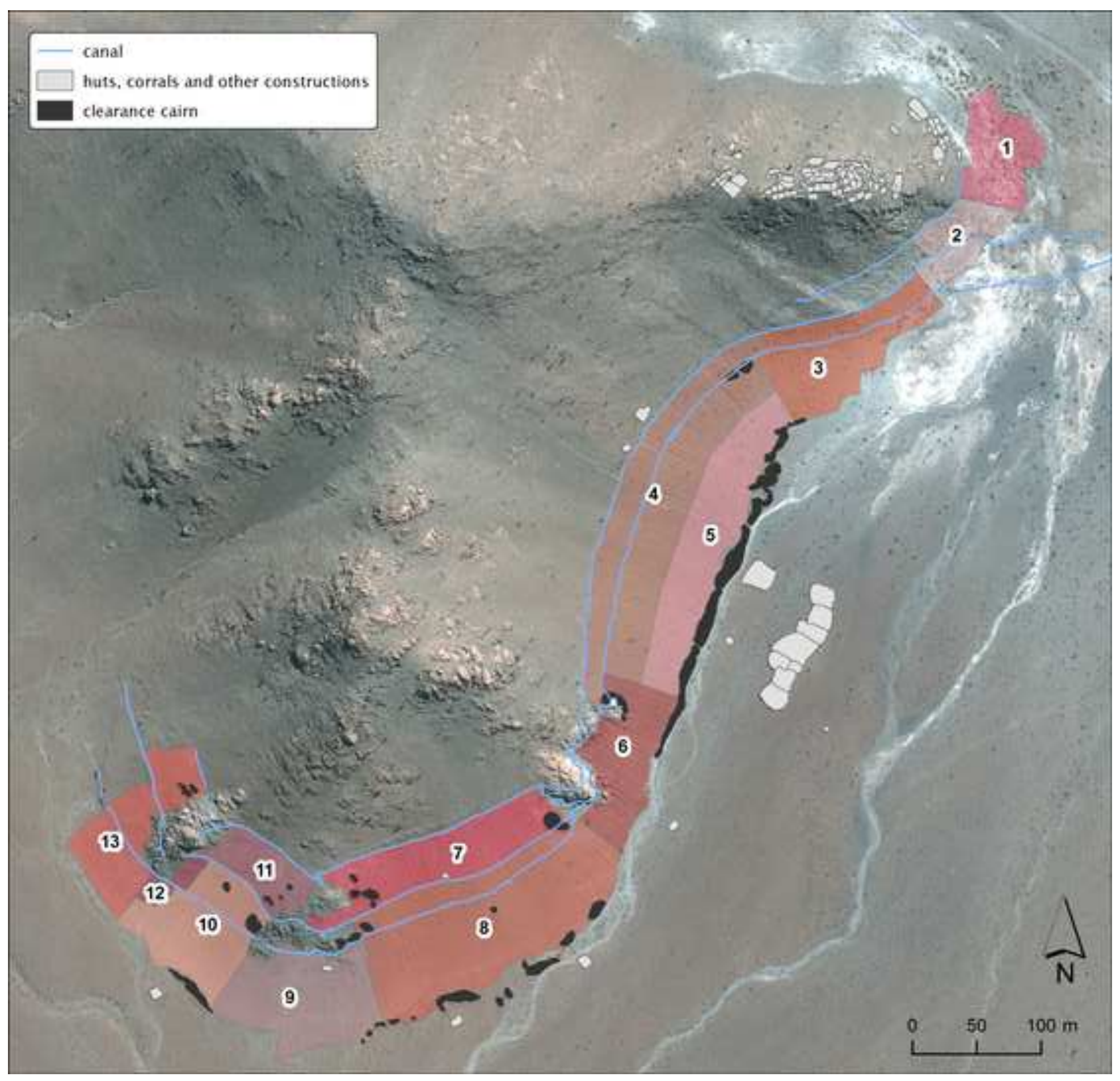




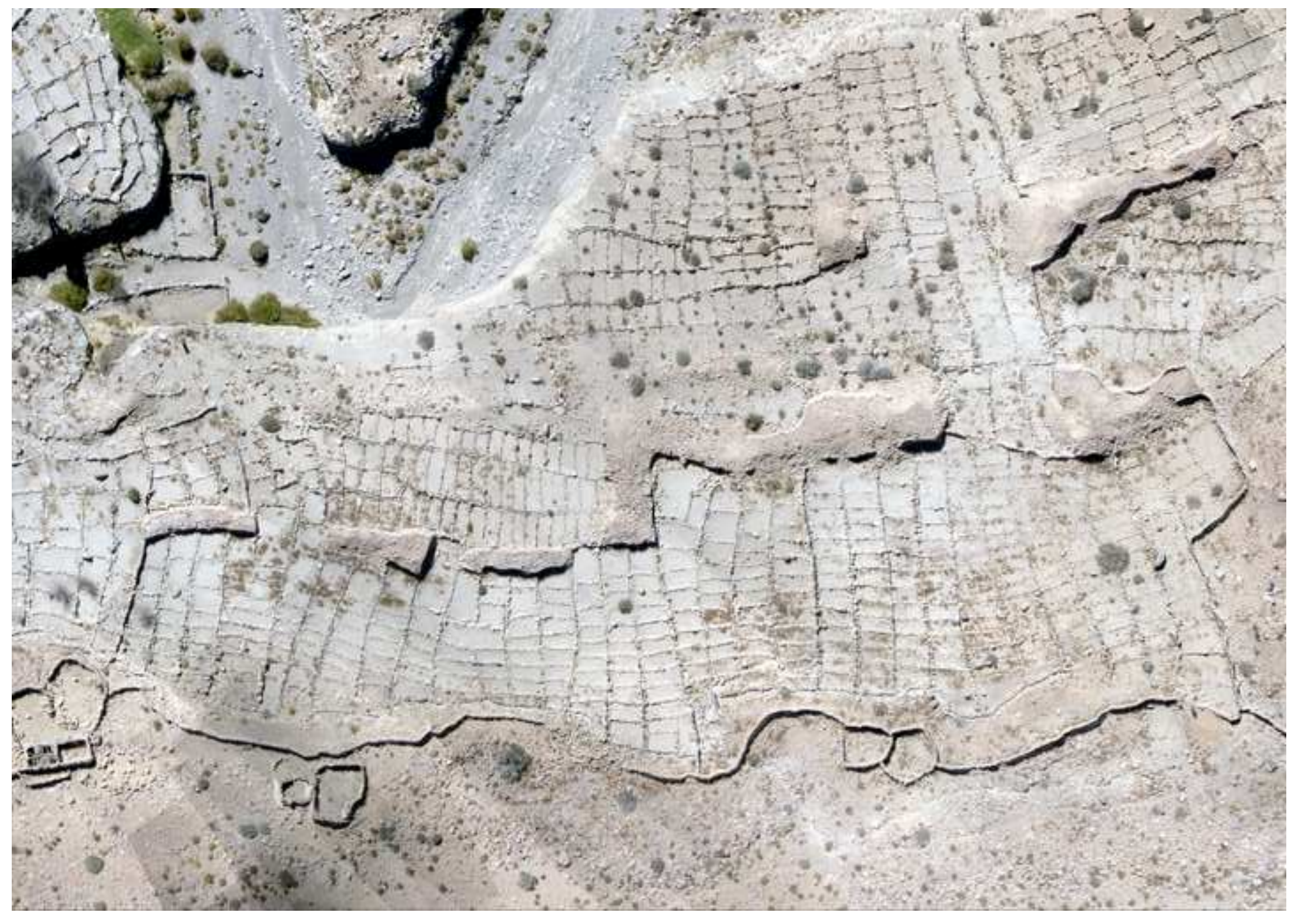




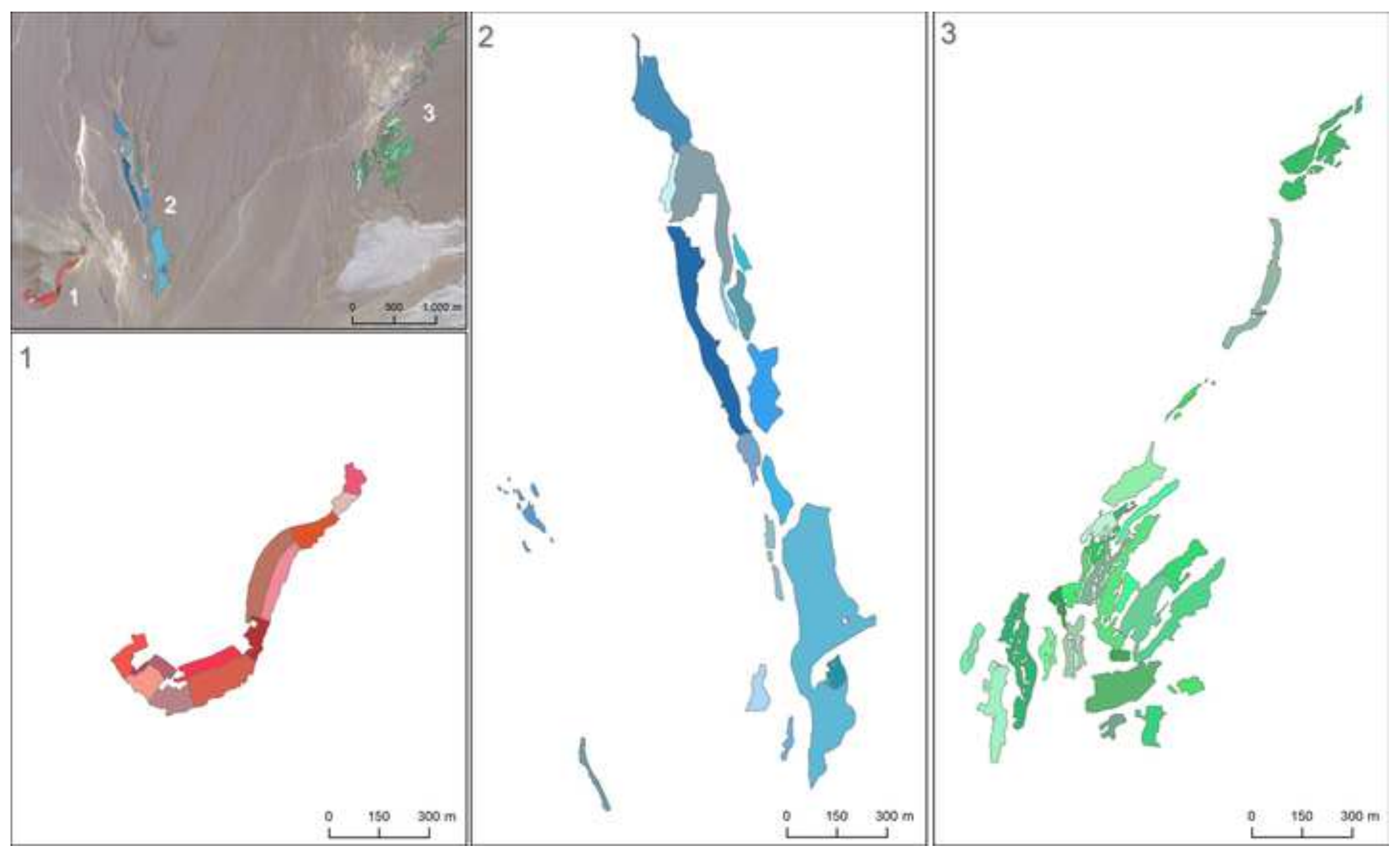




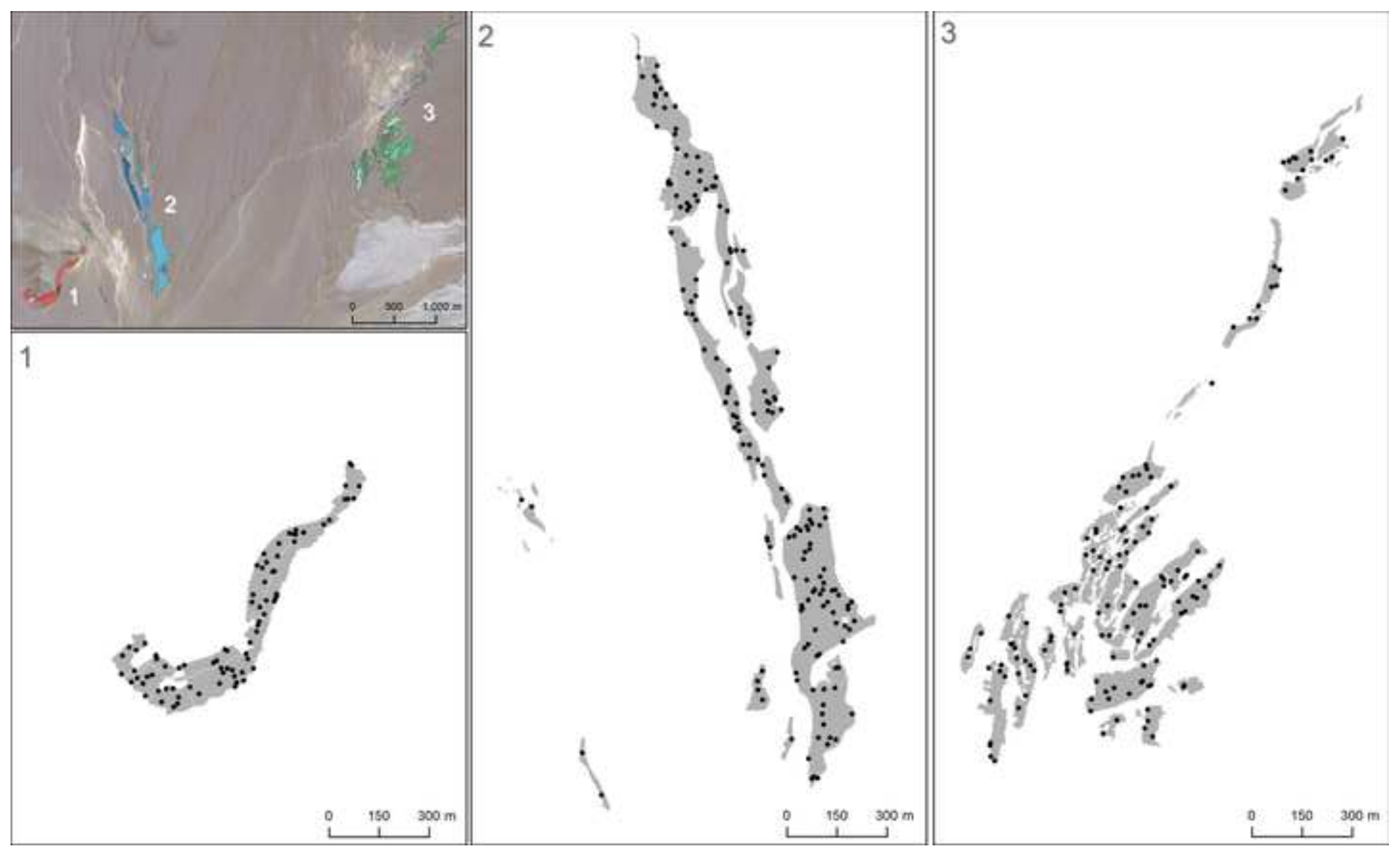




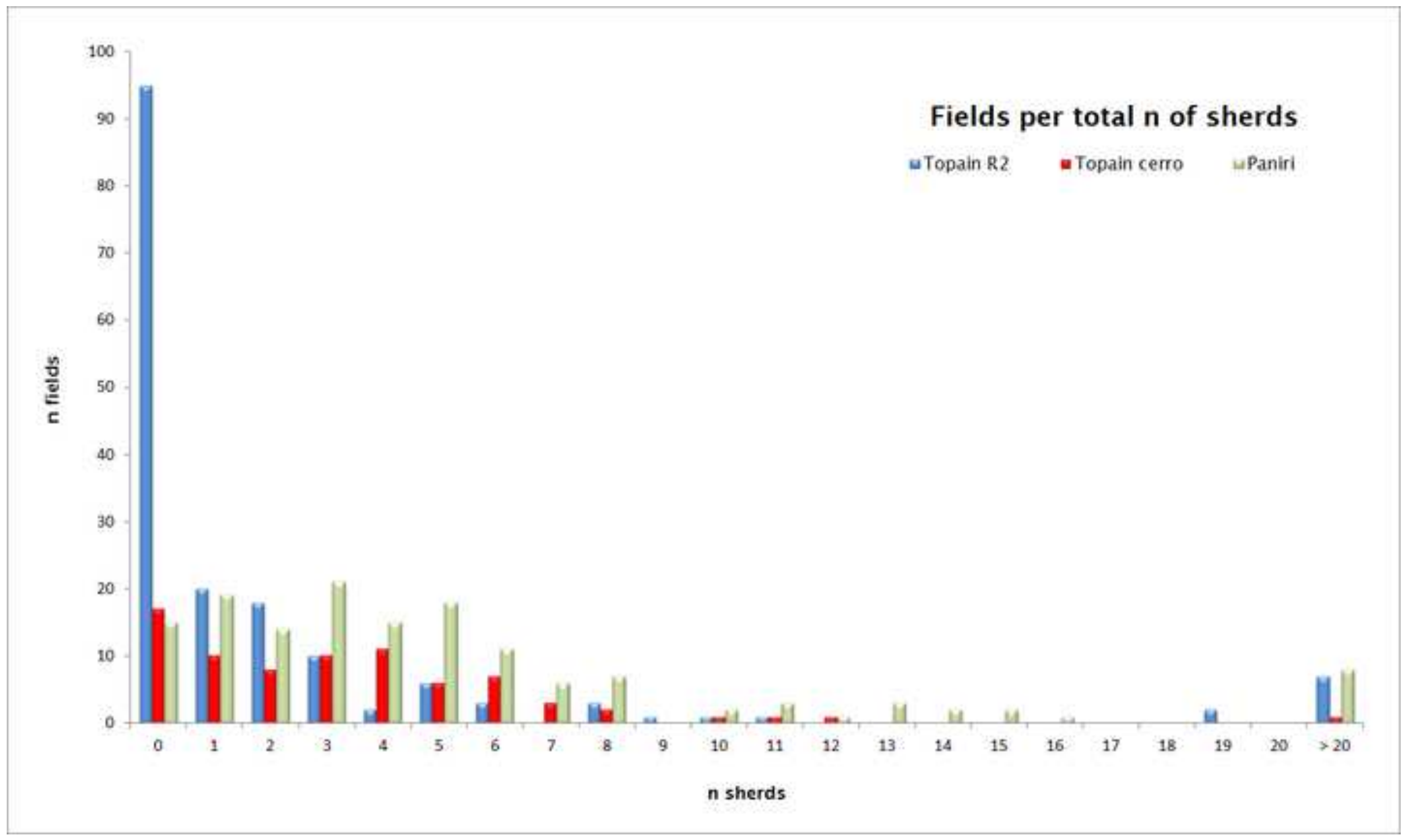




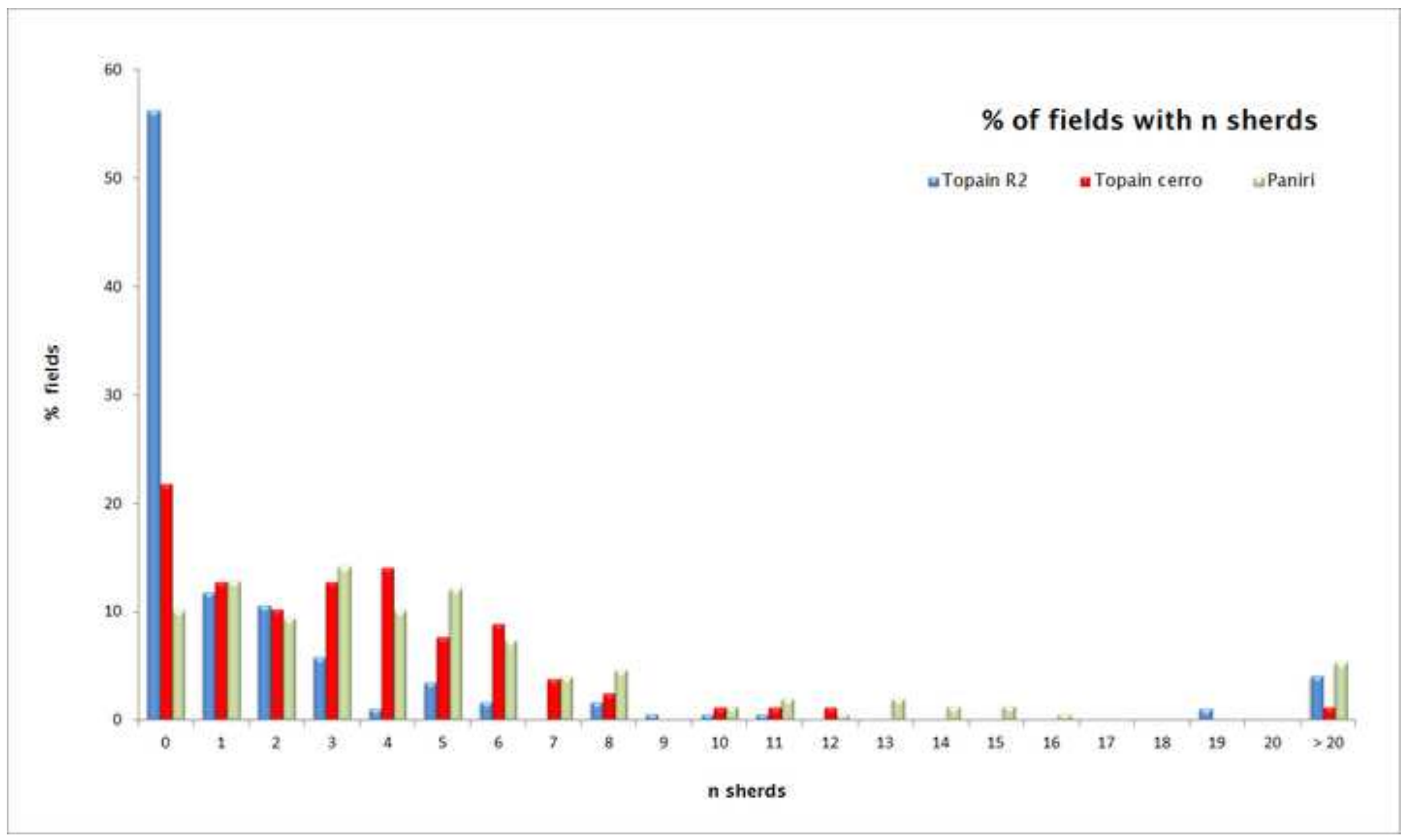




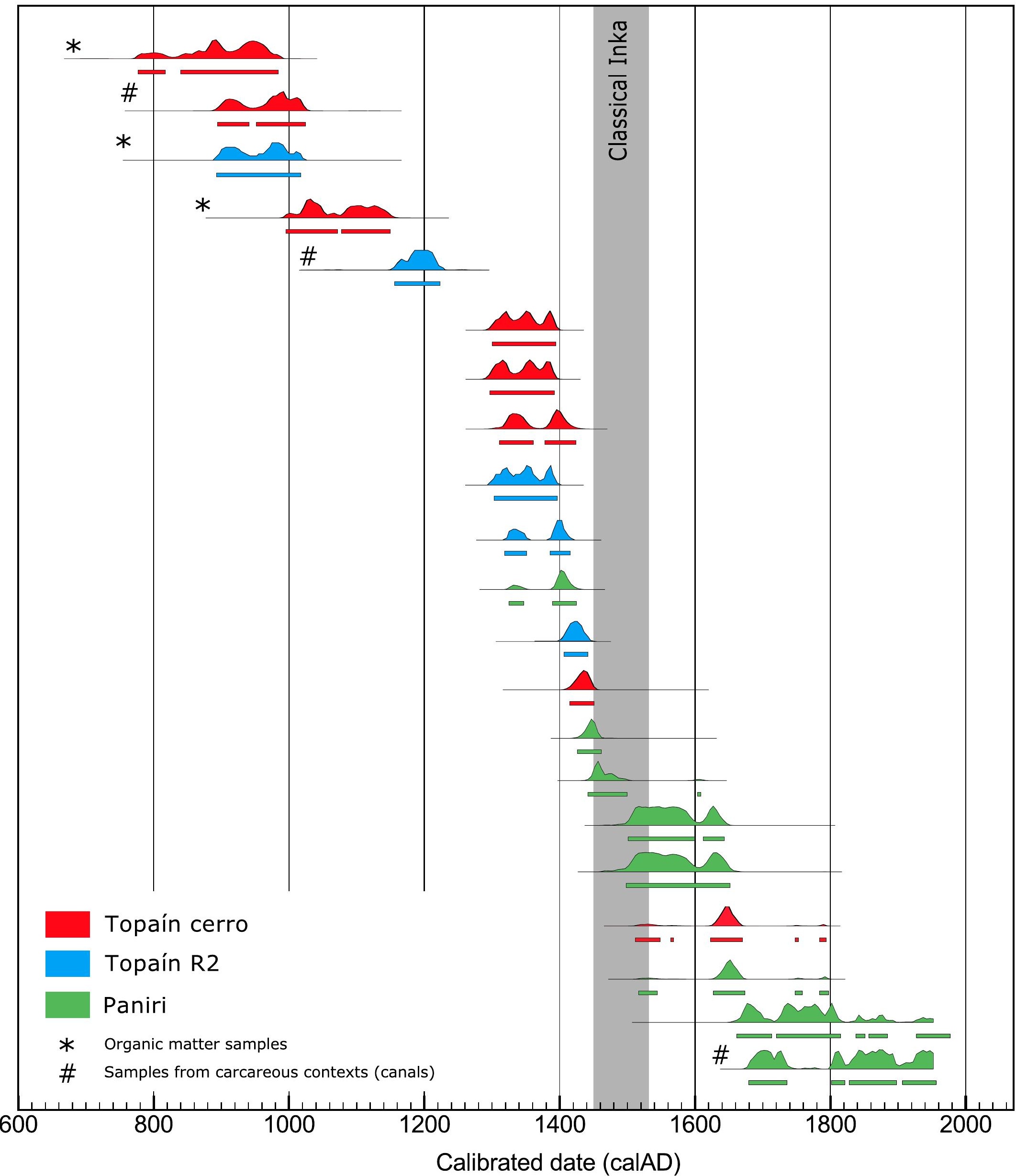




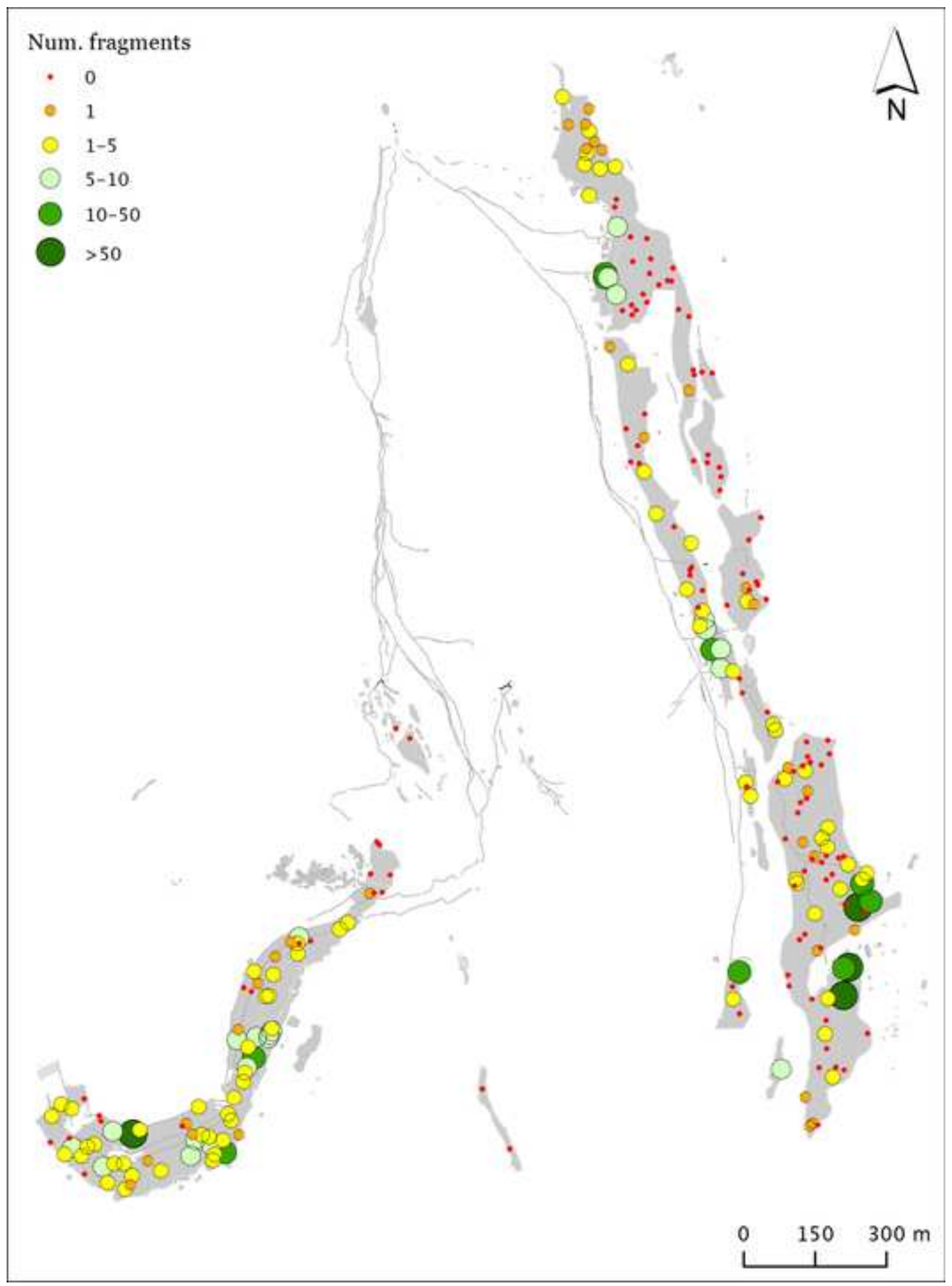




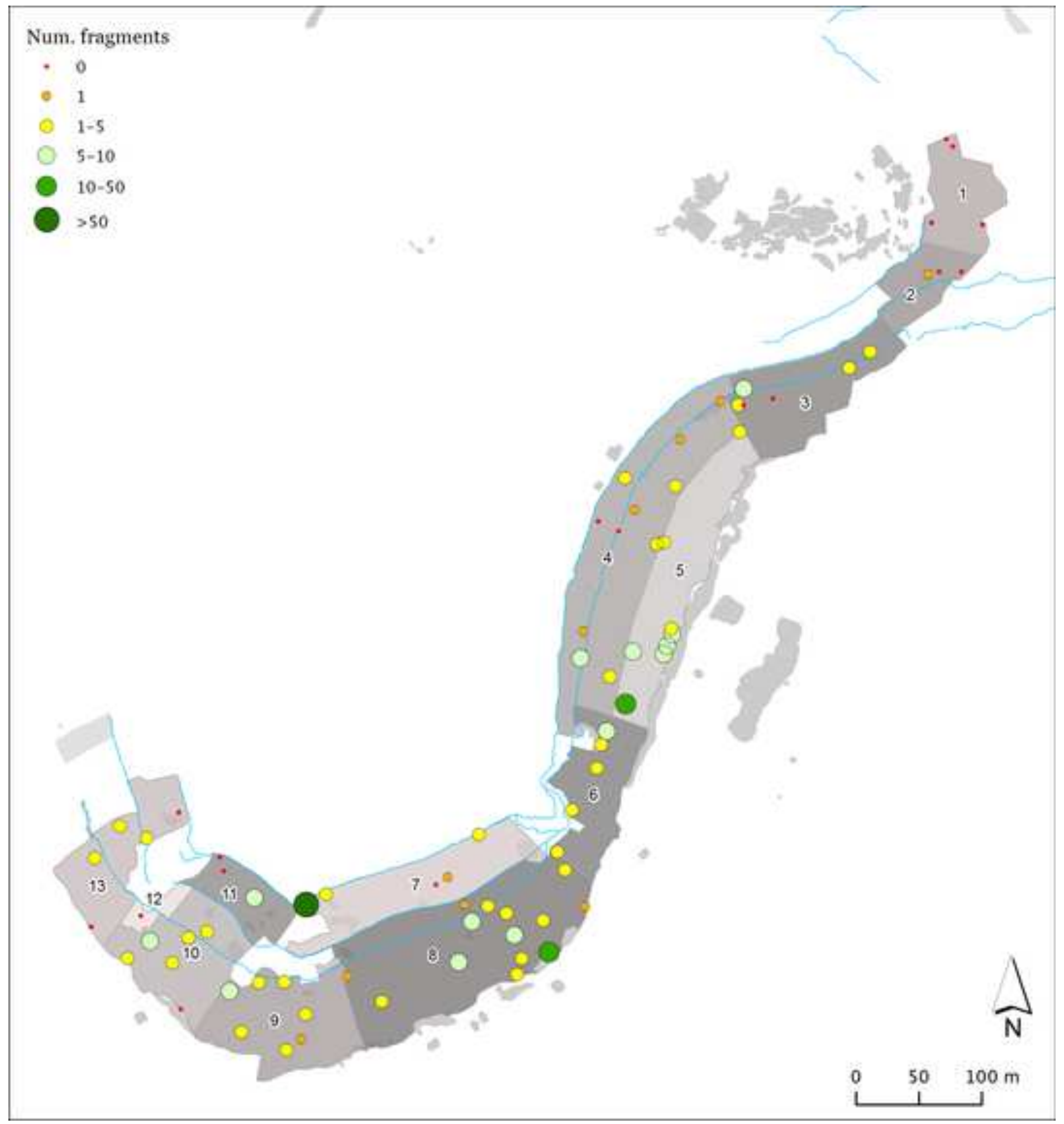




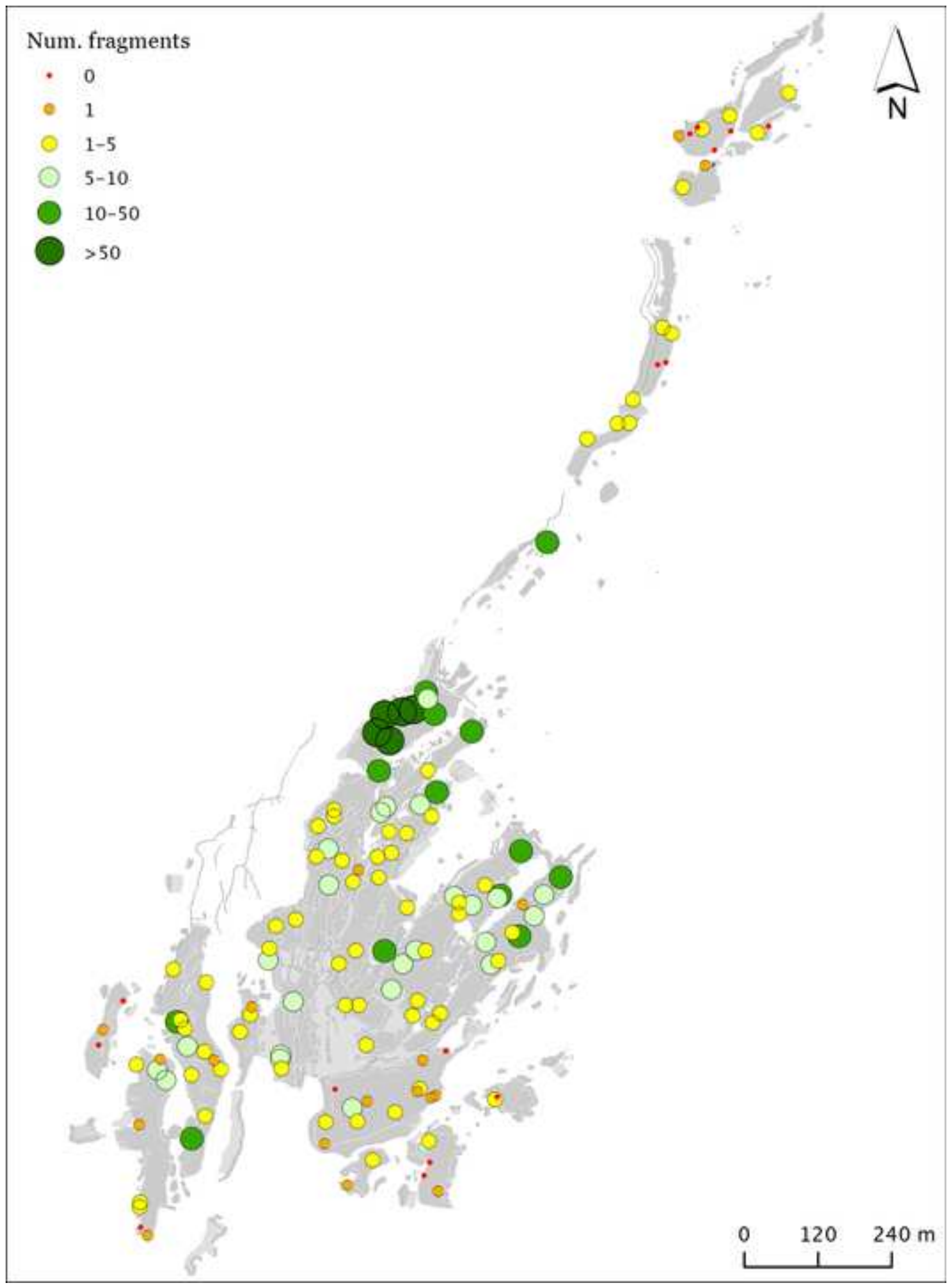




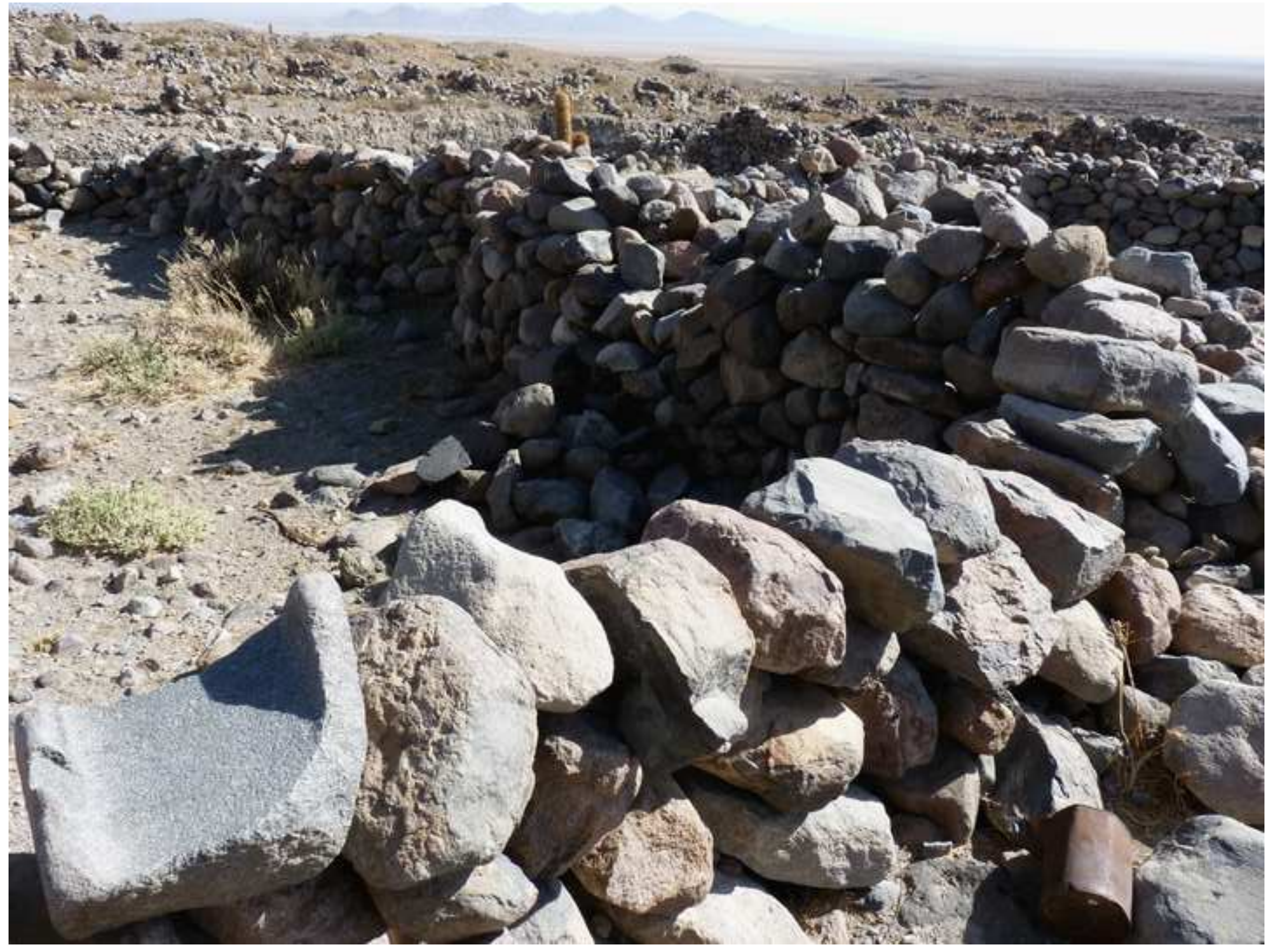




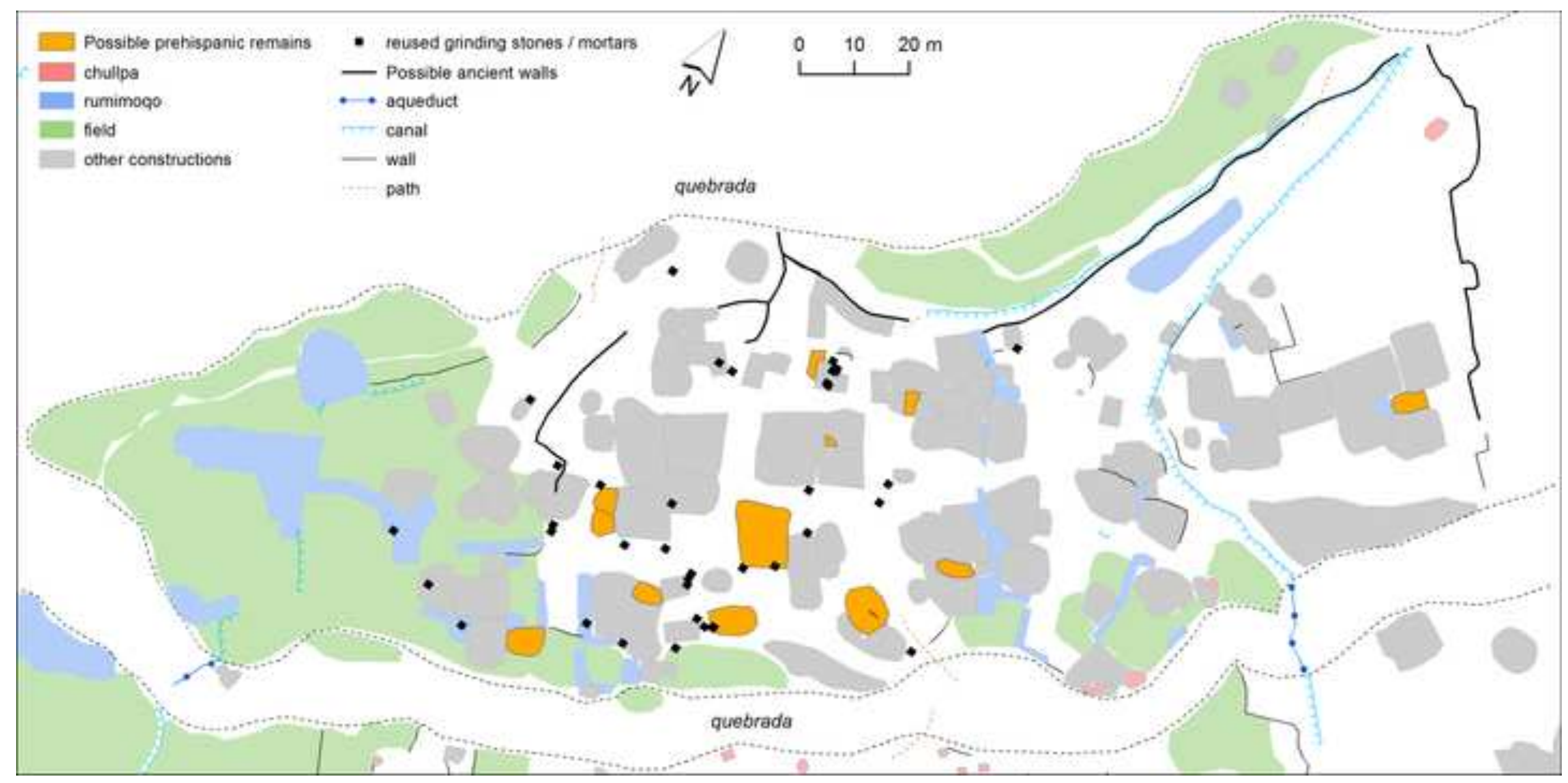




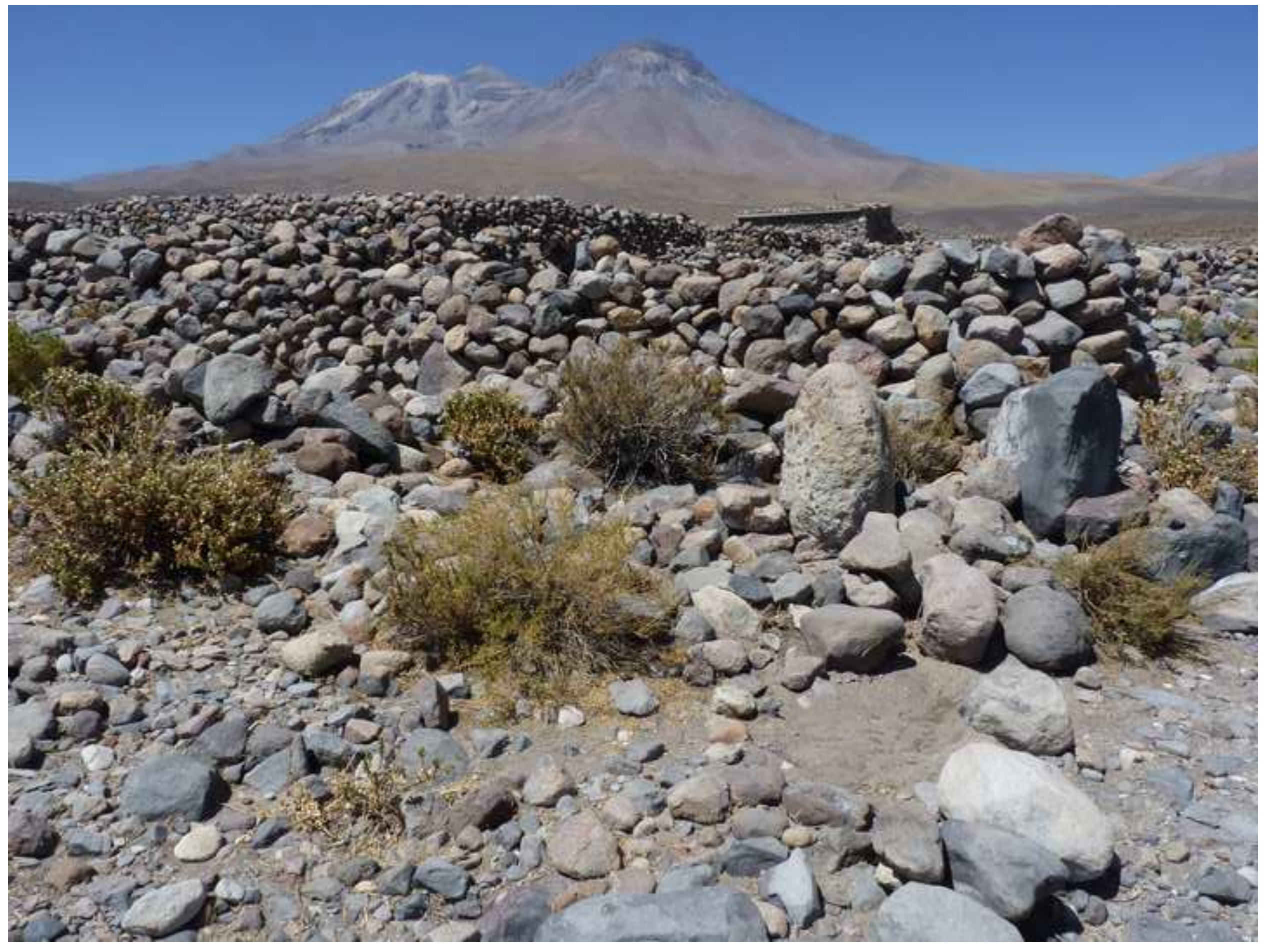




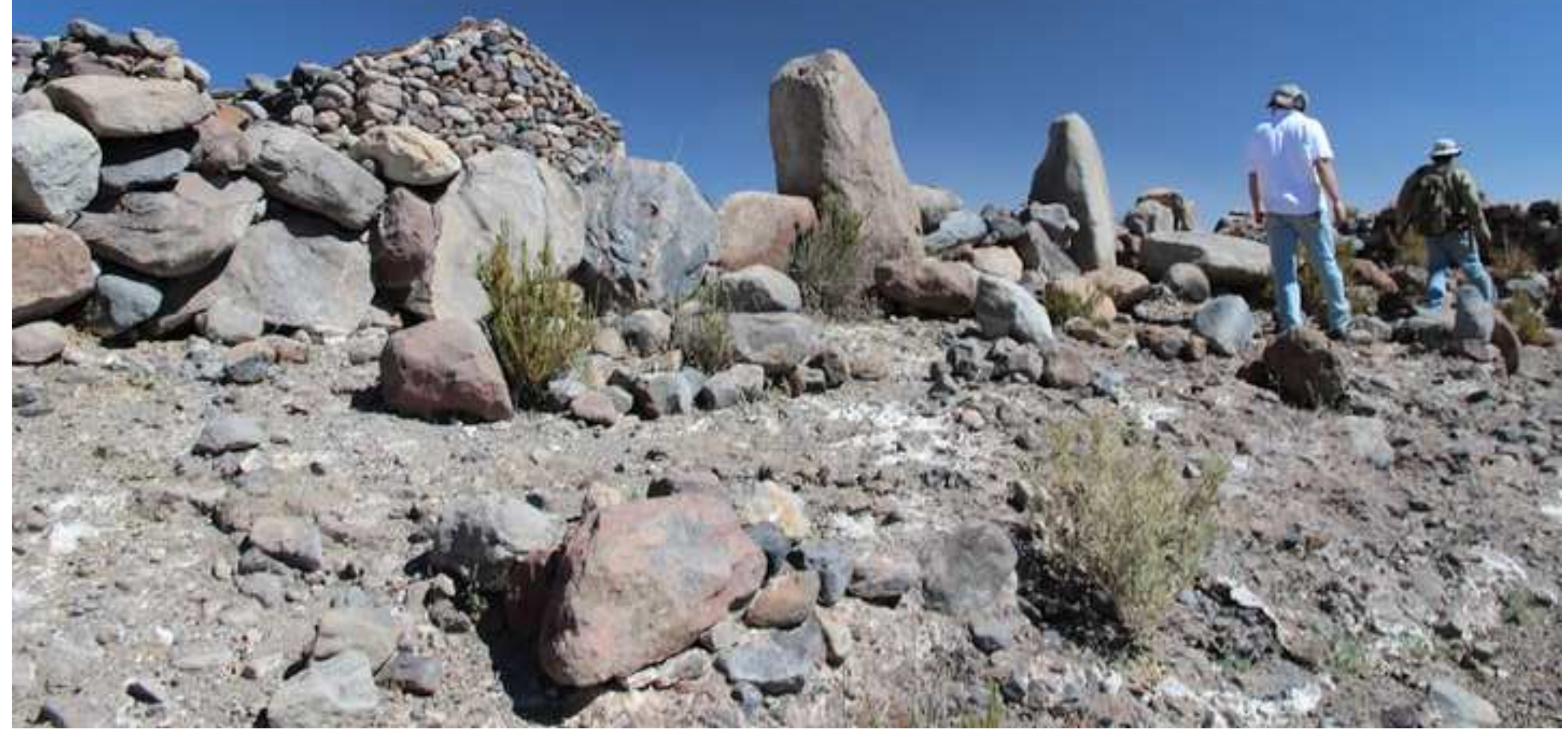




\begin{tabular}{c|ccc|}
\multicolumn{1}{c}{} & Topaín-cerro & Topaín-R2 & Paniri \\
\hline Total area $\left(\mathrm{m}^{2}\right)$ & 93,441 & 255,526 & 208,031 \\
Number of strata & 13 & 17 & 27 \\
Smallest stratum $\left(\mathrm{m}^{2}\right)$ & 851 & 2,088 & 1,150 \\
& & & \\
Largest stratum $\left(\mathrm{m}^{2}\right)$ & 16,548 & 97,410 & 19,063 \\
\end{tabular}




\begin{tabular}{|c|c|c|c|c|c|c|c|c|c|c|c|}
\hline \multicolumn{4}{|c|}{ Topaín-cerro } & \multicolumn{4}{|c|}{ Topaín-R2 } & \multicolumn{4}{|l|}{ Paniri } \\
\hline Strat. & Area & $\mathrm{N}$ & $\mathrm{n}$ & Strat. & Area & $\mathrm{N}$ & $\mathrm{n}$ & Strat. & Area & $\mathrm{N}$ & $\mathrm{n}$ \\
\hline 1 & 5,095 & 1,150 & 4 & 1 & 23,787 & 4,333 & 16 & 1 & 17,895 & 3,260 & 12 \\
\hline 2 & 3,081 & 695 & 3 & 2 & 4,331 & 789 & 3 & 2 & 11,510 & 2,097 & 8 \\
\hline 3 & 7,260 & 1,639 & 6 & 3 & 31,230 & 5,689 & 21 & 3 & 1,978 & 360 & 1 \\
\hline 4 & 15,316 & 3,457 & 13 & 4 & 2,405 & 438 & 2 & 4 & 12,086 & 2,201 & 8 \\
\hline 5 & 8,746 & 1,974 & 7 & 5 & 2,089 & 380 & 1 & 5 & 1,150 & 209 & 1 \\
\hline 6 & 5,490 & 1,239 & 5 & 6 & 7,775 & 1,416 & 5 & 6 & 5,344 & 973 & 4 \\
\hline 7 & 7,389 & 1,668 & 6 & 7 & 32,532 & 5,926 & 22 & 7 & 4,429 & 807 & 3 \\
\hline 8 & 16,548 & 3,735 & 14 & 8 & 17,273 & 3,146 & 11 & 8 & 3,480 & 634 & 2 \\
\hline 9 & 7,945 & 1,793 & 7 & 9 & 5,882 & 1,071 & 4 & 9 & 1,730 & 315 & 1 \\
\hline 10 & 6,705 & 1,514 & 6 & 10 & 7,972 & 1,452 & 5 & 10 & 6,707 & 1,222 & 4 \\
\hline 11 & 3,074 & 694 & 3 & 11 & 4,213 & 767 & 3 & 11 & 16,313 & 2,971 & 11 \\
\hline 12 & 852 & 192 & 1 & 12 & 97,411 & 17,743 & 64 & 12 & 3,489 & 635 & 2 \\
\hline \multirow[t]{17}{*}{13} & 5,940 & 1,341 & 5 & 13 & 3,924 & 715 & 3 & 13 & 2,929 & 534 & 2 \\
\hline & & & & 14 & 5,507 & 1,003 & 4 & 14 & 2,698 & 491 & 2 \\
\hline & & & & 15 & 2,110 & 384 & 1 & 15 & 6,606 & 1,203 & 4 \\
\hline & & & & 16 & 3,320 & 605 & 2 & 16 & 4,263 & 776 & 3 \\
\hline & & & & 17 & 3,767 & 686 & 2 & 17 & 18,356 & 3,343 & 12 \\
\hline & & & & & & & & 18 & 12,926 & 2,355 & 9 \\
\hline & & & & & & & & 19 & 3,846 & 700 & 3 \\
\hline & & & & & & & & 20 & 7,708 & 1,404 & 5 \\
\hline & & & & & & & & 21 & 14,223 & 2,591 & 9 \\
\hline & & & & & & & & 22 & 15,891 & 2,894 & 11 \\
\hline & & & & & & & & 23 & 1,886 & 344 & 1 \\
\hline & & & & & & & & 24 & 19,063 & 3,472 & 13 \\
\hline & & & & & & & & 25 & 2,786 & 507 & 2 \\
\hline & & & & & & & & 26 & 5,649 & 1,029 & 4 \\
\hline & & & & & & & & 27 & 3,092 & 563 & 2 \\
\hline & 93,441 & 21,091 & 80 & & 255,528 & 46,543 & 169 & & 208,033 & 37,890 & 139 \\
\hline & Area & $\mathrm{N}$ & $\mathrm{n}$ & & Area & $\mathrm{N}$ & $\mathrm{n}$ & & Area & $\mathrm{N}$ & $\mathrm{n}$ \\
\hline \multicolumn{4}{|c|}{ Topaín-cerro } & \multicolumn{4}{|c|}{ Topaín-R2 } & \multicolumn{4}{|l|}{ Paniri } \\
\hline
\end{tabular}




\begin{tabular}{|c|c|c|c|c|c|c|c|}
\hline Sector & Sample no & Material & Context & Ref. lab & $\mathrm{BP}$ & +- & Cal 2s \\
\hline \multirow{8}{*}{ 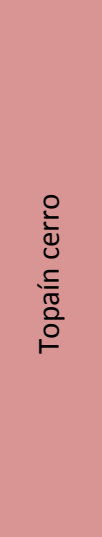 } & MU130316C02 & Organic matter & Cultivation soil & Beta-404776 & 1200 & 30 & $775-983$ \\
\hline & MU130316C09 & Organic matter & Cultivation soil & Beta-404777 & 1030 & 30 & $994-1149$ \\
\hline & MU140718K05 & Charcoal & Cultivation soil & OS-114481 & 520 & 20 & $1415-1450$ \\
\hline & MU140720F06 & Charcoal & Domestic foor & OS-114480 & 670 & 20 & $1300-1394$ \\
\hline & MU140720Z07 & Charcoal & Hearth & OS-114473 & 290 & 20 & $1512-1795$ \\
\hline & MU140725I03 & Charcoal & Domestic floor & OS-114484 & 680 & 20 & $1296-1392$ \\
\hline & MU140725I12 & Charcoal & $\begin{array}{l}\text { Embedded in the wall of a } \\
\text { chullpa }\end{array}$ & Beta-387477 & 620 & 30 & $1310-1424$ \\
\hline & MU140725Z02 & Charcoal & $\begin{array}{l}\text { Embedded in a dam } \\
\text { construction }\end{array}$ & OS-114608 & 1120 & 30 & $893-1023$ \\
\hline \multirow{5}{*}{ 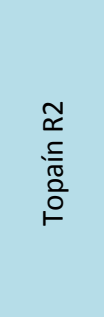 } & MU111214Z01 & Charcoal & Cultivation soil & & 670 & 20 & $1300-1394$ \\
\hline & MU130318C02 & Organic matter & Cultivation soil & Beta-404778 & 1130 & 30 & $892-1018$ \\
\hline & MU140719I07 & Charcoal & Cultivation soil & OS-114472 & 615 & 20 & $1319-1415$ \\
\hline & MU140719K01 & Charcoal & $\begin{array}{l}\text { Embedded in the building } \\
\text { material of a canal, base }\end{array}$ & OS-114477 & 900 & 20 & $1156-1223$ \\
\hline & MU140720002 & Charcoal & Domestic floor (hearth?) & OS-114609 & 550 & 20 & $1404-1441$ \\
\hline \multirow{8}{*}{ : } & MU140721004 & Charcoal & Cultivation soil & Beta-387476 & 340 & 30 & $1497-1650$ \\
\hline & MU140721Z01 & Charcoal & Cultivation soil & OS-114475 & 455 & 20 & $1440-1607$ \\
\hline & MU140723I04 & Charcoal & Cultivation soil & OS-114606 & 285 & 20 & $1515-1796$ \\
\hline & MU140723F03 & Charcoal & $\begin{array}{l}\text { Embedded in the calcareous } \\
\text { material of a canal }\end{array}$ & OS-114479 & 160 & 20 & $1677-1950$ \\
\hline & MU140724H03 & Charcoal & Domestic floor & OS-114476 & 490 & 20 & $1424-1460$ \\
\hline & MU140723Z03 & Charcoal & Cultivation soil & OS-114607 & 200 & 25 & $1660-1950$ \\
\hline & MU140724Z03 & Charcoal & Cultivation soil & OS-114482 & 350 & 20 & $1500-1641$ \\
\hline & MU140725H03 & Charcoal & Domestic floor & OS-114478 & 600 & 20 & $1323-1423$ \\
\hline
\end{tabular}

